\title{
Take (No) Prisoners! The Red Army and German POWs, 1941-1943*
}

\author{
Mark Edele \\ University of Western Australia
}

\section{The Problematic}

From the outset of the German-Soviet war (1941-45), Soviet soldiers, commanders, political officers, and police agents killed captured Germans. Investigation into the reasons and extent, the perpetrators and dynamics of these war crimes was hampered from the start. ${ }^{1}$ One obstacle was that alleged Soviet atrocities were part of German propaganda well before the Wehrmacht's attack on June 22, 1941. The "Commissar Order" of June 6, 1941, decreed the execution of Soviet political officers (politruki, or commissars) should they be captured in battle or while organizing resistance. The order attempted to legitimize this open breach of

* Research for this article was made possible, in part, by a University of Western Australia Research Development Award in 2010 and an Australian Research Council Discovery Grant (DP130101215, 2013-16). It was also supported by very generous colleagues: I would especially like to thank Iva Glisic, Leonid Vaintraub, and Jonathan Waterlow for their help in various archives, and Jürgen Förster, Tsuyoshi Hasegawa, Jochen Hellbeck, Matthew Lenoe, Lennart Samuelson, David Stahel, and Alex Statiev for their many valuable suggestions. The comments of the two readers for the $J M H$ particularly those of David Stone, who generously volunteered to reveal his identityhelped immensely in the task of polishing the final product. I am also grateful to Stewart Candlish for correcting my Teutonic English and to Debra McDougall for editing the final product. Early versions of this paper were presented at the Conference of the Australasian Association for European History, July 2, 2007, Sydney; the American Association for the Advancement of Slavic Studies (AAASS) Annual Convention, Boston, November 13, 2009; the Research Seminar, History Department, the University of Reading, UK, February 2, 2010; the Modern European Social and Cultural History Research Seminar, Faculty of History, Oxford University, February 9, 2010; and the UWA History Seminar, April 14, 2010. More advanced versions were presented at the Annual Convention of the Association for Slavic, East European, and Eurasian Studies, Los Angeles, California, November 18-21, 2010; the conference L'Union soviétique et la Seconde Guerre mondiale, Paris, May 5-7, 2011; the University of Newcastle (Australia) History Research Seminar, April 20, 2012; and the War Studies Seminar at the University of Western Australia, August 15, 2014.

${ }^{1}$ On the general problem of researching perpetration in the Soviet context, see Lynne Viola, "The Question of the Perpetrator in Soviet History," Slavic Review 72, no. 1 (2013): $1-23$.

The Journal of Modern History 88 (June 2016): 342-379 (C) 2016 by The University of Chicago. $0022-2801 / 2016 / 8802-0004 \$ 10.00$ All rights reserved. 
both customary and legal rules of warfare by warning that these "commissars" were the instigators of the "hateful, savage and inhuman treatment of our prisoners"; this was an enemy prone to "barbarian" and "Asiatic" combat methods (barbarisch asiatische Kampfmethoden). ${ }^{2}$ Once fighting did commence, the Wehrmacht War Crimes Unit systematically collected evidence of the enemy's barbarism in an effort to hide the criminality of their own conduct behind a smokescreen of atrocity propaganda masked as legal-medical expertise. ${ }^{3}$ This attempt was successful insofar as some German-language historians have accepted the professionalism of the army's lawyers, taking their research as evidence for a Soviet "war of extermination" against unarmed German prisoners. ${ }^{4}$ This literature in turn has found its way into many of the standard English- and Russian-language treatments, which claim, for example, that "in the early phases

2 "Richtlinien für die Behandlung politischer Kommissare" (June 6, 1941), in Anatomie des SS-Staates, vol. 2, ed. Hans Buchheim et al., 5th ed. (Munich, 1989), 188-91, at 189.

${ }^{3}$ Wehrmacht-Untersuchungsstelle für Verletzungen des Völkerrechts. BundesarchivMilitärarchiv Freiburg (hereafter cited as BA-MA) RW2. On the history of the unit and its connection to propaganda, see "Völkerrechtsverletzungen unserer Gegner auf dem Gebiete des Landkriegsrechts im gegenwärtigen Kriege (Vortrag, gehalten am 28. Januar 1941 in der Deutschen Gesellschaft für Wehrpolitik und Wehrwissenschaften)," BA-MA RW 2/28, esp. fols. 3-8.

${ }^{4}$ See Alfred M. de Zayas, Die Wehrmacht-Untersuchungsstelle. Deutsche Ermittlungen über alliierte Völkerrechtsverletzungen im Zweiten Weltkrieg, 2nd ed. (Munich, 1980), 237-307. De Zayas was still relatively careful: an order to shoot prisoners could not be documented, he wrote, but the German leadership was still convinced, on the basis of the evidence it had seen, that the Red Army followed the rule of shooting prisoners (". . . daß die Sowjetarmee den Grundsatz, deutsche Kriegsgefangene zu erschießen, befolge.” 304). Joachim Hoffmann radicalized this statement into the proposition that prisoner executions were "the rule" (". . . Kriegsgefangene und besonders Verwundete [wurden] in der Regel entweder unmittelbar nach der Gefangennahme oder nach einer ersten Vernehmung erschossen."). See his "Die Kriegführung aus der Sicht der Sowjetunion," in Das Deutsche Reich und der Zweite Weltkrieg, vol. 4, Der Angriff auf die Sowjetunion, ed. Militärgeschichtliches Forschungsamt (Stuttgart, 1983), 713-809, at 785. Hoffmann was citing, without further evidence, de Zayas, 304). The next step of the argument, the declaration that these killings were part of a Soviet "war of extermination," was then developed in Hoffmann's Stalins Vernichtungskrieg 1941-1945, 5th rev. ed. (Munich, 1999), esp. chaps. 10 and 11, which in many ways reads like the Wehrmacht's own accounts. Now also available in English as Stalin's War of Extermination, 1941-1945: Planning, Realization, and Documentation (Capshaw, 2001), and in Russian as Ioakhim Gofman, Stalinskaia voina na unichtozhenie: Planirovanie, osushchestvlenie, dokumenty (Moscow, 2006). For uncritical reproductions of Wehrmacht evidence, see also Franz W. Seidler, Verbrechen an der Wehrmacht. Kriegsgreuel der Roten Armee 1941/42 (Selent, 1997); and Seidler, Kriegsgreuel der Roten Armee. Verbrechen an der Wehrmacht, vol. 2, 1942/43 (Selent, 2000). 
of the war, German prisoners were usually shot, either immediately on capture or after initial interrogation." 5

The Soviet side also contributed to mystifying the issue. Any claim that the glorious Red Army might have committed war crimes was dismissed as slanderous enemy propaganda. Like the German atrocity stories, this counternarrative emerged immediately at the time of the deeds in question and solidified into a historiographical conviction still well entrenched today. The revisionist accounts of the war that have emerged since glasnost have tended to focus on the treatment of Soviet troops and the rampage in Germany in 1945, not on the killings early in the war. ${ }^{6}$ Today, when war crimes are not flatly denied, they are either dismissed as "local excesses" or explained as the result of long years of wartime brutalization and revenge for German barbarity - a line of reasoning also embraced by the mainstream in the English-language literature. ${ }^{7}$

${ }^{5}$ Chris Bellamy, Absolute War: Soviet Russia in the Second World War (New York, 2007), 28-29, quotation at 28. Bellamy's source: Hoffmann. Similarly, without provision of a source: Antony Beevor, The Second World War (New York, 2012), 209, 25. With reference to Seidler's collection, Michael Burleigh, in his Moral Combat: A History of World War II (London, 2010), 241, also claims that "the Soviets had usually killed any captured German soldiers." Slightly more carefully, with reference to de Zayas and to highly dubious German death estimates (see nn. 137 and 158 below): S. P. MacKenzie, "The Treatment of Prisoners of War in World War II," Journal of Modern History 66, no. 3 (1994): 487-520, at 511. Russian examples quoting de Zayas: V. A. Vsevolodov, "Voennoplennye 1941 goda (ideologicheskie, pravovye i voennye aspekty problemy)," in Problemy voennogo plena: Istoriia i sovremennost'. Materialy Mezhudarodnoi nauchnoprakticheskoi konferentsii 23-25 oktiabria 1997 g. b. Vologda. Chast' 2, ed. E. A. Poromonov et al. (Vologda, 1997), 34-44, at 38; N. V. Petrov, "Vnesudebnye repressii protiv voennoplennykh nemtsev v 1941-1946 gg.," in ibid., 77-94, at 77-78; V. B. Konasov, Sudby nemetskikh voennoplennykh v SSSR: Diplomaticheskie, pravovye i politicheskie aspekty problemy. Ocherki, dokumenty (Vologda, 1996), 24-26; Anatolii Iakushevskii, "Rasstrel v klevernom pole. Nemetskie iuristy schitali SSSR v 1941-1945 godakh tozhe sovershal prestupleniia, i sobirali tomu dokazatel'stva," Novoe vremia, no. 25 (1993): 40-42, also seems to draw on de Zayas, although no source is given. Aleksandr Gogun, Stalinskie kommandos. Ukrainskie partizanskie formirovaniia 1941-1944, 2nd rev. ed. (Moscow, 2012), 212-13, draws on Hoffmann.

${ }^{6}$ For notable exceptions to this rule, see, in addition to the literature mentioned in the previous footnote, Izvestiia TsK KPSS, no. 10, 1990, 214-16, which first published evidence for Stalin suggesting executions in 1941; and Iurii Rubtsov, "Plennykh ia prikazyvaiu konchat ...' Bez grifa 'sekretno'," Krasnaia zvezda, July 27, 1994, 4, which first published evidence that Mekhlis did the same. For an introduction to the historiography with an extensive bibliography, see, V. B. Konasov and A. L. Kuz'minykh, Nemetskie voennoplennye v SSSR: Istoriograpfiia, bibliografiia, spravochno-poniatiinyi apparat (Volgograd, 2002).

${ }^{7}$ For example, E. S. Seniavskaia, 1941-1945. Frontovoe pokolenie. Istorikopsikhologicheskoe issledovanie (Moscow, 1995); V. K. Luzherenko, "Plen: Tragediia millionov," in Velikaia Otechestvennaia voina 1941-1945. Voenno-istoricheskie ocherki. V chetyrekh knigakh. Kniga 4: Narod i voina, ed. V. A. Zolotarev and G. N. Sevost'ianov 
Given the ongoing politicization of the issue in Russia and the contamination of the German records by propagandistic intent, sources are a problem. The Soviet military archive in Podolsk (TsAMO) remains closed for this kind of research. The documentary record produced by the German side, meanwhile, cannot be taken at face value. It provides a prism into a world where rumor was taken as seriously as the rotting corpses in the woods. ${ }^{8}$ Nevertheless, if read with care, archival files produced by the Wehrmacht remain a valuable resource. ${ }^{9}$

We can indeed be sure that Soviet crimes against POWs did happen. The German evidence sometimes triangulates statements of survivors with those of Soviet witnesses as well as with forensic evidence. Particularly valuable are trophy documents that the Germans took during the war, which are contained in the files of military intelligence on all levels of the German army. Wherever possible, I have worked with the Russian-language originals, although sometimes only a translation was preserved, and attempts to follow the original from one administrative level to the next often led only to further translations, the original being continually forwarded on and eventually lost. ${ }^{10}$

Thankfully, these are not the only sources. Some Soviet and post-Soviet memoirists describe these deeds in detail, breaking the official silence and the ongoing denial. We now also have a smattering of archival evidence from the Soviet side, some of it published, some directly accessible either in the Russian state archives or in the Volkogonov papers held by the Library of Congress. Finally, the published discourse in the newspapers Pravda and Krasnaia zvezda

(Moscow, 1999), 168-204, esp. 195; Konasov and Kuz'minykh, Nemetskie voennoplennye, 23. For English-language accounts with the same linear narrative of barbarization: Norman M. Naimark, The Russians in Germany: A History of the Soviet Zone of Occupation, 1945-1949 (Cambridge, MA, 1995); Evan Mawdsley, Thunder in the East: The NaziSoviet War 1941-1945, 2nd rev. ed. (London, 2016), 101; and Catherine Merridale, Ivan's War: Life and Death in the Red Army, 1939-1945 (New York, 2006). Anthony Beevor plays down revenge in 1944-45, and stresses lack of discipline, sexual frustration, and alcohol instead. See his The Fall of Berlin 1945 (London, 2003).

${ }^{8}$ On German intelligence's preconceptions, see Jürgen Förster, "Conoscenza e pregiudizio. L'Unione Sovietica vista dei servizi segreti militari tedeschi," Storia e Memoria 2 (2003): 13-28; and, more generally, Förster, "Zum Rußlandbild der Militärs 1941-1945," in Das Rußlandbild im Dritten Reich, 141-63. See also David Thomas, "Foreign Armies East and German Military Intelligence in Russia 1941-45," Journal of Contemporary History 22, no. 2 (1987): 261-301.

${ }^{9}$ For examples of careful use of German evidence about Red Army behavior, see Manfred Zeidler, Kriegsende im Osten. Die Rote Armee und die Besetzung Deutschlands östlich von Oder und Neisse 1944/45 (Munich, 1996); Christian Hartmann, Wehrmacht im Ostkrieg. Front und militärisches Hinterland 1941/42, 2nd ed. (Munich, 2010).

${ }^{10} \mathrm{I}$ have noted in the footnotes when translations are made from German translations rather than Russian originals. If not noted otherwise, trophy documents are quoted from the Russian original. 
in particular provide a lot of valuable contextual information. ${ }^{11}$ The central empirical question is thus not whether war crimes against German POWs happened, but why they happened and how often they occurred. It is the task of this article to find answers to these twin questions.

Building on several careful studies transcending linear accounts of piecemeal Soviet brutalization, ${ }^{12}$ as well as on approaches that posit the unleashing of an "integral brutality" inherent either in the Soviet system ${ }^{13}$ or in Soviet society, ${ }^{14}$ this article shows that there was a dynamic that at first glance seems counterintuitive. At the beginning of the war, prisoner executions were frequent, but not universal. The fall and winter of 1941 and early 1942 saw an escalation of the practice, partially because from November 1941 onward many believed that Stalin had given an order to "kill each and every German." This signal was reversed only in February 1942. From then on, a process of normalization set in that decreased the likelihood that German captives would be executed. Meanwhile, throughout the early part of the war, inside orders - from Stalin all the way down to field commanders - were inconsistent, demanding either the taking or the execution of POWs: Soviet policy was contradictory during this period and so were the results. Moreover, orders alone do not explain many of these acts, which occurred in complex local situations. Perceived military necessity was reinforced by the relentless atrocity propaganda of the Soviet side from the outset of the war, which itself drew on broader traditions of violence in word and deed.

As far as the frequency of prisoner executions is concerned, this article concludes on the basis of both Soviet and German archival materials that the murder and mutilation of prisoners by the Soviets was less common than

\footnotetext{
${ }^{11}$ On newspaper propaganda during the war, see Karel C. Berkhoff, Motherland in Danger: Soviet Propaganda during World War II (Cambridge, MA, 2012).

${ }^{12}$ The best discussion thus far is Hartmann, Wehrmacht im Ostkrieg, 542-49. See also Christian Streit, Keine Kameraden. Die Wehrmacht und die sowjetischen Kriegsgefangenen 1941-1945 (Bonn, 1997), 227, 400 n. 24; Andreas Hilger, Deutsche Kriegsgefangene in der Sowjetunion, 1941-1956. Kriegsgefangenenpolitik, Lageralltag und Erinnerung (Essen, 2000), 54-63; Dieter Pohl, Die Herrschaft der Wehrmacht. Deutsche Militärbesatzung und einheimische Bevölkerung in der Sowjetunion 1941-1944 (Frankfurt, 2011), 205-6; Petrov, "Vnesudebnye repressii”"; also available in a German version: "Außergerichtliche Repressionen gegen kriegsgefangene Deutsche 1941 bis 1956," in Die Tragödie der Gefangenschaft in Deutschland und in der Sowjetunion 1941-1956, ed. Klaus-Dieter Müller et al. (Cologne, 1998), 175-96.

${ }^{13}$ Amir Weiner, "Something to Die For, a Lot to Kill For: The Soviet System and the Barbarisation of Warfare, 1939-1945," in The Barbarization of Warfare, ed. George Kassimeris (New York, 2006), 101-25.

${ }^{14}$ Oleg Budnitskii, "The Intelligentsia Meets the Enemy: Educated Soviet Officers in Defeated Germany, 1945," Kritika: Explorations in Russian and Eurasian History 10, no. 3 (2009): 629-82.
} 
Germans at the time and some later historians believed. By analyzing Soviet behavior in a comparative context encompassing not only its German counterpart but also that of other belligerents in both the Second World War and beyond, I conclude that while Soviet war crimes cannot and should not be denied, they have more in common with prisoner executions in other times and places than with the Germans' premeditated war of extermination.

This article is not an exhaustive treatment of Soviet war crimes for a number of reasons. First, I focus on deeds committed by members of the Red Army rather than acts of the Soviet secret police (the NKVD) or the irregulars (the "partisans"). Partisan warfare poses its own problems with regard to prisoner taking, which warrants its own study. ${ }^{15}$ The NKVD was responsible for further "processing" of enemy soldiers who survived capture by the Red Army or Stalin's guerrillas, which for some turned out to be lethal. At this stage of the development of the historiography, we have only a very unclear picture of what happened in this phase of the war between the handover of prisoners to the NKVD at POW collection points and their arrival in POW camps. The necessary research remains impossible as long as access to the archives of the Federal Security Service (FSB, the successor of the KGB) is highly restrictive at best. ${ }^{16}$ Second, I concentrate on German POWs, not those of other nationalities. Overall, the Soviets registered 4.1 million enemy captives, 2.4 million (59 percent) of them Germans and 156,682 Austrians; the others were everything from Japanese to Hungarians, Swedes to Chinese, and even included 10,173 Jews. ${ }^{17}$ Their fates would deserve their own investigations. Third, I examine the period between the surrender of soldiers and their delivery to the NKVD collection points, not on the better-known story of their suffering and death in captivity, or on the conviction of some as war criminals. ${ }^{18}$ Finally, my

${ }^{15}$ On partisans' treatment of their prisoners, see John A. Armstrong, Soviet Partisans in World War II (Madison, WI, 1964), 222-23; Theo J. Schulte, The German Army and Nazi Policies in Occupied Russia (Oxford, 1989), 123-24, 138, 260; Kenneth Slepyan, Stalin's Guerrillas: Soviet Partisans in World War II (Lawrence, KS, 2006), 156; Bogdan Musial, Sowjetische Partisanen 1941-1944: Mythos und Wirklichkeit (Paderborn, 2009), 88, 92, 557 n. 180, 270-71; Hartmann, Wehrmacht im Ostkrieg, 757; and Gogun, Stalinskie kommandos, 213-14, 217.

${ }^{16}$ On NKVD killings, based on FSB archive files, see Petrov, "Vnesudebnye repressii." See also Bernhard Chiari, Alltag hinter der Front. Besatzung, Kollaboration und Widerstand in Weißrußland 1941-1944 (Düsseldorf, 1998), 305; and Vadim J. Birstein, SMERSH. Stalin's Secret Weapon: Soviet Military Counterintelligence in World War II (London, 2011), 139-42.

${ }^{17}$ V. P. Galitskii, "V poiskakh pravdy. Vrazheskie voennoplennye v SSSR (1941-1945 gg.)," Voenno-istoricheskii zhurnal, no. 9 (1990): 39-46, at 45-46.

${ }_{18}$ Stefan Karner, Im Archipel GUPVI. Kriegsgefangenschaft und Internierung in der Sowjetunion 1941-1956 (Vienna, 1995); Hilger, Deutsche Kriegsgefangene; Arkadij Krupennikov, "Gerichtsverfahren gegen Kriegsverbrecher Ende der vierziger und Anfang 
focus is on the beginning of the war rather than the oft-told end, which has been covered in great detail by others.

\section{THE POLICY}

The most obvious explanation for the killing of Germans prisoners in 1941 and 1942 would be the existence of a central policy, similar to the German Commissar Order but more universal: to exterminate all the brutes. ${ }^{19}$ Given the precedent of the centrally ordered mass shooting of Polish officers in Katyn and elsewhere in 1940, or the executions of civilian prisoners in the Western Borderlands in 1941, this theory cannot be dismissed a priori. ${ }^{20}$ The Germans certainly thought there was an order from Stalin to take no prisoners, despite all evidence to the contrary. ${ }^{21}$

There was no such policy. The Soviets did capture enemy soldiers from the outset of this war, and they established an entire infrastructure to deal with them. ${ }^{22}$ The 1941 mobilization plans included provisions for POW reception centers to be run by the NKVD. And while the Soviet Union had not signed the Geneva Convention Relating to Prisoners of War (1929), the government indicated early in the war that it would feel bound by the Hague Convention

der fünfziger Jahre," in Die Tragödie der Gefangenschaft, 197-214; Manfred Zeidler, Stalinjustiz contra NS-Verbrechen. Die Kriegsverbrecherprozesse gegen deutsche Kriegsgefangene in der UdSSR in den Jahren 1943-1952. Kenntnisstand und Forschungsprobleme (Dresden, 1996); Alexander Prusin, "'Fascist Criminals to the Gallows!': The Holocaust and Soviet War Crimes Trials, December 1945-February 1946," Holocaust and Genocide Studies 17, no. 1 (2003): 1-30.

${ }^{19}$ The existence of such a policy is sometimes assumed: see, e.g., Niall Ferguson, The Pity of War (New York, 1999), 394.

${ }_{20}$ On Katyn: Anna M. Cienciala, Natalia S. Lebedeva, and Wojciech Materski, eds., Katyn: A Crime without Punishment (New Haven, CT, 2007); Inessa Iazhborovskaia, Anatolii Iablokov, and Valentina Parasadanova, Katynskii sindrom v sovetsko-pol'skikh $i$ rossiisko-pol'skikh otnosheniiakh (Moscow, 2009). On the 1941 mass executions: Bogdan Musial, "Konterrevolutionäre Elemente sind zu erschießen”. Die Brutalisierung des deutsch-sowjetischen Krieges im Sommer 1941, 2nd ed. (Berlin, 2001); Karel C. Berkhoff, Harvest of Despair: Life and Death in Ukraine under Nazi Rule (Cambridge, 2004), 1417; Rebecca Manley, To the Tashkent Station: Evacuation and Survival in the Soviet Union at War (Ithaca, NY, 2009), 45-46.

${ }^{21}$ Oberkommando der Wehrmacht, Wehrmacht-Untersuchungsstelle für Verletzungen des Völkerrechts: "Kriegsverbrechen der russischen Wehrmacht 1941" (November 1941), BA-MA RW 2/145, esp. fols. 3-6; and "Kriegsverbrechen der russischen Wehrmacht, Band 2," BA-MA RW 2/149, fols. 5-11.

${ }^{22}$ For an overview: Viktor Muchin, "Das System der Gefangennahme, Erfassung, Versorgung und Weiterleitung sowjetischer und deutscher Kriegsgefangener in frontnahen Gebieten 1941 bis 1945. Eine vergleichende Analyse," in Die Tragödie der Gefangenschaft, 107-28. 
(1907), which the tsarist government had ratified. Shortly after the war started, on July 1, the Supreme Soviet had passed a set of regulations for POWs (Polozhenie o voennoplennykh) that laid down a detailed policy for the treatment of enemy captives. ${ }^{23}$ German counterintelligence obtained a copy at the front line ${ }^{24}$ and judged it to be in rough correspondence with the Hague Convention. ${ }^{25}$ On July 9, the Political Administration of the Red Army issued a directive to organize propaganda among German POWs, ${ }^{26}$ and a Soviet High Command (Stavka) order from August 3 demanded that all captured officers, noncommissioned officers, and pilots be forwarded "immediately" to the General Staff's Counterintelligence Administration in Moscow. ${ }^{27}$ On August 24 the commander of the Briansk front, A. I. Eremenko, reported by phone that prisoners had been taken and intelligence had been obtained from them. ${ }^{28}$ During the battle for Kalinin in October, twenty-two POWs were captured, among them two officers. ${ }^{29}$ Soon the numbers added up. According to the agency's own records, the camps of the NKVD's Administration for Affairs of POWs and the Interned (Upravlenie po delam voennoplennykh i internirovannykh, or UPVI, later "Main Administration" or GUPVI) processed 9,147 POWs in 1941, while in 1942, before the liquidation of the encircled Germans

${ }^{23}$ Streit, Keine Kameraden, 224-26; Galitskii, "V poiskakh pravdy," 42. The Polozhenie is reprinted in several places. For example: Voennoplennye v SSSR. 1939-1956. Dokumenty i materialy, ed. M. M. Zagorul'ko (Moscow, 2000), 65-68.

24 "Polozhenie o voennoplennykh, utverzhdeno Postanovleniem SNK SSSR 1-go iiulia 1941 goda no. 1798-800s," BA-MA RW 2/154, unpaginated pages between fols. 103 and 104.

${ }^{25}$ Amt Ausl/Abw., Abt. Ausland, Geheime Vortragsnotiz, Berlin den 23.5.1942, BAMA RW 2/154, fol. 190. For divergence of this legislation from international law, in particular the Geneva protocol, see V. L. Khavkin, "Nemetskie voennoplennye v SSSR i sovetskie voennoplennye v germanii. Postanovka problemy. Istochniki i literatura," in Problemy voennogo plena, 3-13, at 8; see also V. B. Konasov and A. V. Tereshchuk, "K istorii sovetskikh i nemetskikh voennoplennykh (1941-1943 gg.)," Novaia i noveishaia istoriia, no. 5 (1996): 54-72, esp. 59.

${ }^{26}$ V. A. Zolotarev, ed., Glavnye politicheskie organy vooruzhennykh sil SSSR v Velikoi Otechestvennoi voine 1941-1945 gg. Dokumenty i materialy. (= Russkii Arkhiv. Velikaia Otechestvennaia), vol. 17-6 (Moscow, 1996), 34 (hereafter cited as RA/VO) 17-6 (1-2): 34).

${ }^{27}$ Order signed Shaposhnikov, August 3, 1941, Tsentral'nyi arkhiv Ministerstva Oborony RF (TsAMO) f. 3, op. 11556, d. 1, 1. 257, in Library of Congress, Volkogonov Papers, container 7, folder 1. From a different archival source also reprinted in RA/VO 16 (5-1): 100.

${ }^{28}$ Record of phone conversation, Shaposhnikov and Eremenko, in RA/VO 16 (5-1): $131-34$, at 131.

${ }^{29}$ Abramov (commander of 30th Army) to Beriia (October 24, 1941), reprinted in Lubianka v dni bitvy za Moskvu, ed. V. K. Vinogradov (Moscow, 2002), 222. 
at Stalingrad, 10,635 were registered. ${ }^{30}$ By 1943, the Soviets had spent over 214 million rubles on their POW camp system. ${ }^{31}$

The Polozhenie o voennoplennykh was used in agitation tempting Germans to desert, but it was much more than a propaganda ploy. ${ }^{32}$ A joint letter of the Medical Administration of the Red Army, the Red Army's Supply Administration, and the UPVI, dated July 29, 1941, and referring to the Polozhenie o voennoplennykh, laid out the policy of how to evacuate, process, feed, and give medical attention to POWs. ${ }^{33}$ An order by the Chief of the Red Army's General Staff, Marshall Shaposhnikov, demanded the Polozhenie's implementation by fronts and armies, ${ }^{34}$ and a document of October 3, 1941, signed by Lev Mekhlis of the Main Political Administration of the Red Army, spelled out very detailed regulations for the interrogation and indoctrination of enemy captives. ${ }^{35}$

Clearly, then, there was no Soviet policy mandating the wholesale liquidation of enemies. From the beginning of the war, the formal Soviet policy was to take prisoners and treat them according to their status as POWs. Nevertheless, from the very start of the conflict, soldiers executed captives, a practice higher commanders of the Red Army tried to stop as extremely counterproductive. An order by the Chief of Political Propaganda of the XXXI Rifle Corps to his counterpart in the 193rd Rifle Division, dated July 14, 1941, noted that "in battle, Red Army men and commanders do not capture soldiers and officers. We know of cases where captives were strangled and stabbed to death [dushat i zakalyvaiut]. Such a relationship toward captives damages the Red Army politically, embitters the soldiers of the fascist army, hinders the process of its dissolution, while giving material to the officers of the fascist army to deceive the soldiers about the 'atrocities' of captivity by the Red Army and strengthens the resistance of the soldiers." He thus ordered: "By all means of party-political work explain to the personnel of units and subunits the extremely damaging nature of a relationship to captives unworthy of the Red Army. Explain that the German soldier is a worker

30 "Dokladnaia zapiska uchetnogo otdela 1-go Upravleniia GUPVI NKVD SSSR rukovodstvu Upravleniia ob itogakh raboty za period s 1941 g. po ianvar' 1945 g." (February 5, 1945), in Voennoplennye v SSSR 1939-1956. Tom 4: Glavnoe Upravlenie po delam voennoplennykh i internirovannykh NKVD-MVD SSSR 1941-1952. Otchetnoinformatsionnye dokumenty i materialy, ed. M. M. Zagorul'ko (Volgograd, 2004), 197201, at 197.

${ }^{31}$ I. V. Bezborodova, "Organizatsiia trudoispol'zovaniia voennoplennykh i internirovannykh v lageriakh NKVD-MVD SSSR v gody vtoroi mirovoi voiny," in Problemy voennogo plena, 50-58, at 51 .

32 "Listovka GLAVPU RKKA 'Polozhenie o voennoplennykh v Sovetskom soiuze" (July 5, 1941), in RA/VO 24-13 (3): 16-17.

${ }_{33}$ BA-MA RW 2/154, fol. 57 (Russian original).

${ }^{34}$ Order of Shaposhnikov to Chiefs of Staff of fronts and armies (Russian original), before December 30, 1941, BA-MA RW 2/154, unpaginated pages between fols. 83 and 84. For dating: ibid., fol. 30.

${ }^{35}$ A translation is contained in BA-MA RH 19 III/444, fols. 207-14. 
and a peasant. He fights not of his own will. That once the German soldier surrenders, he stops being an enemy. Take all measures to capture German soldiers and in particular officers. ${ }^{" 36}$ Already on June 30 a very similar order had come down from the commander of the 5th Army, General-Major Potapov, to the commander of the 195th Rifle Division; ${ }^{37}$ on July 22 the commander of the VI Rifle Corps forbade the common practice of shooting prisoners, ${ }^{38}$ and on August 25 the commander of the 88th Rifle Division demanded that POWs be blindfolded, but also that they be fed and evacuated behind the lines. ${ }^{39}$ By September 8 some units still executed their prisoners rather than forwarding them, but this earned them rebukes from their superiors. ${ }^{40}$

Often, indeed, commanders sought to end much smaller transgressions than killing enemy prisoners. In his order demanding implementation of the Polozhenie, Shaposhnikov complained:

We know of instances where individual soldiers took the personal effects of POWs, [including] valuable items, money, and documents. The registration of POWs and trophy goods is not organized.

The Chiefs of Staff of fronts and armies and scouting units do not know where captives came from, where they have been captured, what weapons and personal effects were taken from them. Such lack of accountability and control enables illegal occurrences on the part of individual servicemen. ${ }^{41}$

A similar complaint was raised in a sharply worded order by General-Major Gordov, Chief of Staff of the 21st Army, and his commissar, Brigade-Commissar Pogodin, to the commander of a rifle corps. That this communication was copied to the military prosecutor of the 21st Army and the Chief of the Special Section shows how seriously senior commanders took the issue of POWs being robbed upon captivity - to say nothing of their execution. ${ }^{42}$

\section{SignALS FROM ABOVE}

From the beginning, however, the official line was inconsistent. ${ }^{43}$ Stalin's personal files contain the transcript of a phone conversation with Zhukov on

${ }^{36}$ BA-MA RW 2/154, fols. 50-52, at 50 (Russian original).

${ }^{37}$ BA-MA RW 2/154, fol. 49 (Russian original).

${ }^{38}$ BA-MA RW 2/154, fol. 100 (German translation; original lost).

${ }^{39}$ BA-MA RW 2/154, unpaginated pages between fols. 83 and 84 (Russian original).

${ }^{40}$ BA-MA RW 2/154, fols. 134-35 (German translation; original lost).

${ }^{41}$ BA-MA RW 2/154, unpaginated pages between fols. 83 and 84 (Russian original).

${ }^{42}$ BA-MA RW 2/154, fols. 45-46 (Russian original). The undated order was given between July 19 and August 8, 1941. See ibid., fol. 33 .

${ }^{43}$ Contradictory policies were not untypical early in the war. See Anna Krylova, Soviet Women in Combat: A History of Violence on the Eastern Front (Cambridge, 2010); and Gogun, Stalinskie kommandos, 28. 
October 15, 1941, in which the dictator dismissed the intelligence obtained by prisoner interrogations: "Don't believe prisoners of war too much. Interrogate them under duress, and then shoot them." 44 This was an offhand remark, to be sure, not a formal order, but in the Stalinist dictatorship, suggestions by the boss carried enormous weight as "signals from above." Subordinates were used to interpreting much vaguer remarks as signals with a broader meaning and acting accordingly. ${ }^{45}$ And indeed, further down the hierarchy, explicit killing orders were sometimes given, clearly on the assumption that these were legitimate or at least would be tolerated by the dictator. Stalin's right-hand man, Lev Mekhlis, while serving as a "fully empowered representative of Stavka" in the Crimea in early 1942, wrote to his son: "In the city of Kerch up to seven thousand corpses of civilians (including children) [were found], all shot by the fascist monsters. . . . One's blood runs cold from anger and the thirst for revenge. I order the killing of the fascist prisoners." 46

Such orders were isolated exceptions to official policy, but from the first days of the war the media disseminated information on enemy atrocities, including the barbarous treatment of captives. This discourse was further radicalized when, on November 6, 1941, Stalin publicly called for an escalation of warfare against the Germans. ${ }^{47}$ Citing German trophy documents, the supreme leader launched into a tirade that would soon become famous among the troops: "The German invaders want a war of extermination [istrebitel' naia voina] with the peoples of the USSR. Well, then, if the Germans want a war of extermination, they will get it. . . . Henceforth our task, the task of the peoples of the USSR, the task of the soldiers, commanders, and political workers of our army and navy will be to exterminate [istrebit'] each and every German who has forced his way as an occupier onto our

${ }^{44}$ Rossiiskii Gosudarstvennyi Arkhiv Sotsial'no-politicheskoi istorii (RGASPI) f. 558, op. 11, d. 487, 1. 73. This phone conversation is omitted from those published in RA/VO 16 (5-1).

${ }^{45}$ On the centrality of Stalin's "signals," see Sheila Fitzpatrick, Everyday Stalinism: Ordinary Life in Extraordinary Times: Soviet Russia in the 1930s (New York, 1999), 2428; see also Oleg V. Khlevniuk, Master of the House: Stalin and His Inner Circle (New Haven, CT, 2009).

${ }^{46}$ Iurii Rubtsov, Alter ego Stalina. Kniga sozdana na osnove rassekrechennykh dokumentov iz arkhivnykh fondov (Moscow, 1999), 215.

${ }^{47}$ Mark Edele and Michael Geyer, "States of Exception: The Nazi-Soviet War as a System of Violence, 1939-1945," in Beyond Totalitarianism: Stalinism and Nazism Compared, ed. Michael Geyer and Sheila Fitzpatrick (Cambridge, 2009), 345-95, at 365, 368-69, 385. On hate propaganda more generally, see, inter alia, Richard Stites, ed., Culture and Entertainment in Wartime Russia (Bloomington, IN, 1995); Jeffrey Brooks, Thank You, Comrade Stalin! Soviet Public Culture from Revolution to Cold War (Princeton, NJ, 2000), chap. 7; Hoffmann, "Die Kriegführung aus der Sicht der Sowjetunion," 782-85; Berkhoff, Motherland in Danger; and Julie K. deGraffenried, Sacrificing Childhood: Children and the Soviet State in the Great Patriotic War (Lawrence, KS, 2014), chap. 4. 
homeland." 48 This speech, printed in Pravda and thus widely available to propagandists, became the centerpiece of a hate campaign at the front line that had started at the beginning of the war but now was ratcheted up significantly. ${ }^{49}$

Stalin's words were deliberately vague in order to allow public denial if necessary but still signal a policy change to the rank and file. They could be read in a variety of ways, and soldiers at the front line debated which reading was correct. ${ }^{50}$ If a soldier surrendered, did he cease being an occupier? The consistent orders, before and after Stalin's speech, to spare prisoners' lives, seemed to support an affirmative answer. ${ }^{51}$ Prisoners therefore continued to be taken after Stalin's speech:52 "3rd Squadron seized a German," jotted an officer in his notebook on December 12. He "was forwarded to the LVII Corps." ${ }^{53}$ In the same month, even diversionist groups operating behind the lines of the enemy brought captives back. ${ }^{54}$ Moreover, Stalin himself continued to order the capture of enemies. On December 13, Stalin and Shaposhnikov directed Zhukov to surround the enemy in the area of Klin and to offer to spare the Germans' lives if they surrendered, but, should they refuse, to "destroy them to the last man." 55 On December 17, likewise, the pair ordered the commander of the Leningrad front to transition from defense to attack. The enemy should be surrounded in order to "capture or destroy him." ${ }^{, 56}$ In an order to his subordinates, Zhukov also clarified that "comrade Stalin has never spoken of the shooting of enemy soldiers if they give themselves up or come over to us voluntarily."

${ }^{48}$ Pravda, November 7, 1941, 1-2, at 2.

${ }^{49}$ See the directives of the Main Political Administration of the Red Army, nos. 0178 and 268 of November 14, 1941, and December 7, 1941, respectively. Reprinted in RA/ VO 17-6 (1-2): 83-84, 87-90.

${ }^{50}$ Letter by D. D. Delov from political department of rear areas, Kalinin Front, December 1941, in Lubianka $v$ dni bitvy za Moskvu, 295; NKVD report on mood of soldiers at Kalinin Front (January 1, 1942), in ibid., 307-10, at 309.

${ }^{51}$ See for example, "Prikaz No. 168 Kavallereiskomu polku 41 OKD, No. 168" (December 28, 1941), BA-MA RW 2/154, fol. 123; or Battle Order of Staff of Coastal Army, Sevastopol, of December 2, 1941, BA-MA RW 2/27, fols. 6-7.

${ }^{52}$ For examples from November and December, see, e.g., General Staff of Red Army, Military History Department, "Razgrom nemetskikh voisk pod Moskvoi, chast' I," (1943), RGASPI f. 558, op. 3, d. 300, 1. 19, 1. 45 (marked "secret").

${ }^{53}$ Diary of an unknown officer of the 46th Cavalry Division, entry of December 14, 1941, BA-MA RW 2/158, fols. 197-213, at 202.

${ }^{54}$ Scouting report, not before December 15, 1941, Lubianka $v$ dni bitvy za Moskvu, 175.

${ }^{55}$ TsAMO f. 3, op. 11556, d. 4, 1. 261, in Volkogonov Papers, container 7, folder 1. From a different archival source also reprinted in RA/VO 16 (5-1): 333-34.

${ }_{56}$ TsAMO f. 3, op. 14556, d. 4, 11. 303-4, in Volkogonov Papers, container 6. From a different archival source also reprinted in RA/VO 16 (5-1): 338.

${ }^{57}$ Hoffmann, "Die Kriegführung aus der Sicht der Sowjetunion," 789 (citing an undated trophy document from BA-MA). 
As Zhukov's clarification implies, however, Soviet citizens, long accustomed to guessing at the intentions behind ambiguous signals from above, often understood Stalin's instruction as a direct command to execute prisoners: "Stalin says we need to exterminate all Germans," wrote one soldier in a private letter. ${ }^{58}$ In the shortened form in which commanders and agitators passed it on to the troops, the escalation speech became a "secret order" to give no quarter. As one Red Army man recounted such creative reception, "during the issuing of orders, starting on November 6, 1941, our commissar [politruk] read to us daily that Stalin, in his radio address of November 6, 1941, has ordered that all Germans who are found on Russian soil, irrespective if they are Volksdeutsche or German POWs, should be exterminated completely. We were told to act accordingly." 59 A soldier interrogated by his German captors in late December 1941 claimed that "between December 4 and 8, 1941-I cannot remember the exact date — our platoon leader read us an order by Stalin, which said that we were not allowed any more to take any German prisoners. All German prisoners and captured wounded soldiers were to be shot immediately." ${ }^{60}$ Another POW reported that his platoon leader, during a prebattle briefing in January 1942, passed on the command of the regimental commissar that "we now don't take prisoners, all Germans need to be destroyed, nobody should stay alive."

The November 6 speech and its rendering by frontline propagandists radicalized the troops' behavior toward captured Germans. The Soviet offensive outside Moscow in December witnessed a new wave of prisoner killings. ${ }^{62}$ In the period before the beginning of the Stalingrad Strategic Offensive Operation on November 19, 1942, the average daily intake of German POWs dropped from fortyseven per day in 1941 to only thirty-three per day in much of 1942 (fig. 1). Partially, this was a result of less vicious fighting, particularly during the months of April, June, October, and November of $1942 .{ }^{63}$ However, a comparison with German military deaths in approximately the same periods suggests that prisoner taking declined more radically than the death toll: while the daily prisoner average

\footnotetext{
${ }^{58}$ NKVD report on mood of troops, Kalinin Front (December 22, 1941), Lubianka $v$ dni bitvy za Moskvu, 294.

${ }^{59}$ He was interrogated by German counterintelligence in late 1941 or early 1942, BAMA RW 2/149, fol. 8 .

${ }^{60}$ BA-MA RW 2/149, fols. $8-9$ (translation from the German).

${ }^{61}$ Photocopy of interrogation protocol, January 22, 1942, BA-MA RW 2/152, fol. 8 (Russian original).

${ }^{62}$ See Hartmann, Wehrmacht im Ostkrieg, 384.

63 "Viciousness" has been measured here by monthly death tolls, which during these months were significantly lower than in others. See Rüdiger Overmans, Deutsche militärische Verluste im Zweiten Weltkrieg (Munich, 1999), 277 (table 59).
} 


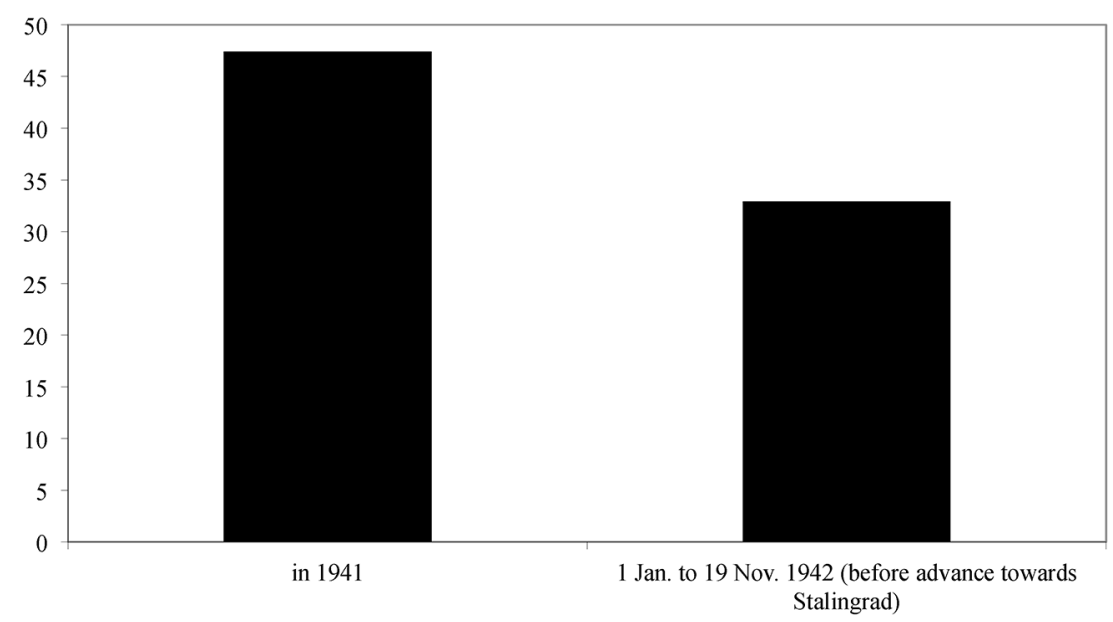

FIG. 1.-Average POWs registered per day before the start of the Stalingrad campaign. Source for raw data: Voennoplennye v SSSR 1939-1956. Tom 4: Glavnoe Upravlenie po delam voennoplennykh i internirovannykh NKVD-MVD SSSR 1941-1952. Otchetnoinformatsionnye dokumenty i materialy, ed. M. M. Zagorul'ko (Volgograd 2004), 197.

declined by 30 percent in 1942, the average monthly death toll declined by only 16 percent. $^{64}$

A more fine-grained data set on prisoner taking in 1941 suggests the impact of Stalin's November speech as well, but it also shows that signals from above are only part of the explanation. Indeed, table 1 demonstrates that, as a rule, the Red Army took fewer prisoners when retreating and more when advancing. The average daily intake of prisoners rose from forty-eight in the first month of the war to reach a high of 108 in the final ten days of August. Thereafter it reverted to the level of the first month, then fell even further to reach only twenty-seven in the final three months of the year. The 1942 average of thirty-three, then, already marks a recovery from this low point. The rise of the numbers in August and their decline in September are best explained by the nature of Soviet operations. After the rout of June and July, the Soviets counterattacked at Smolensk beginning on July 23, followed by the Dukhovshchina and El'nia counteroffensives in August; the rise in the daily prisoner averages coincides with these military efforts. Once these major counteroffensives were over and the German advance resumed in the

${ }^{64}$ This calculation has taken the average monthly death toll for the six full months of fighting in 1941 (July-December) and compared it to the average for the months before the Stalingrad debacle (January-November). The respective numbers are 46,249 (1941) and 38,914 (1942). Calculated from Overmans, Deutsche militärische Verluste, 277 (table 59). 
TABLE 1

Average Number of German POWs Registered Daily IN NKVD RECEPTION POINTS, 1941

\begin{tabular}{lc}
\hline \hline Period & $\begin{array}{c}\text { Average Daily } \\
\text { Number of POWs }\end{array}$ \\
June 22 to July 22, 1941 & 48 \\
July 23 to August 1, 1941 & 89 \\
August 2-20, 1941 & 86 \\
August 21-31, 1941 & 51 \\
September 1-October 1, 1941 & 27 \\
October 2, 1941-January 1, 1942 & 58 \\
\hline SouRCES.- “Obzor deiatel'nosti frontovykh organov GUPVI NKVD SSSR \\
v period Velikoi Otechestvennoi voiny” (no later than June 20, 1951), in \\
Glavnoe upravlenie po delam voennoplennykh i internirovannykh NKVD-MVD \\
SSSR 1941-1952. Otchetno-informatsionnye dokumenty i materialy, ed. M. M. \\
Zagorul'o (Volgograd, 2004), 139-81, at 148; “Dokladnaia zapiska uchetnogo \\
otdela 1-go Upravleniia GUPVI NKVD SSSR rukovodstvu Upravleniia ob \\
itogakh raboty za period s 1941 g. po ianvar' 1945 g,” (February 5, 1945), in \\
ibid., 197-201, at 197.
\end{tabular}

battle of Kiev starting in September, prisoner numbers declined again to a level similar to those of June and early July. ${ }^{65}$

This is as far as a purely operational explanation can lead, however. The collapse of the prisoner intake during the Red Army's counteroffensive in the winter of 1941/42 to only twenty-seven per day on average for the period October 2, 1941, to January 1, 1942, remains inexplicable if we do not consider the change in signals from Stalin. During its counteroffensive outside Moscow the Red Army took fewer prisoners than it had during the hectic retreat in June and July 1941. Purely military explanations, then, need to be supplemented with an analysis of the interaction of signals from above and reactions on the ground, a dynamic specific to the way the Stalinist dictatorship worked in practice. The dictator often radicalized his underlings by sending broad signals encouraging them to escalate their activities. Then, when the escalation had gone too far, he

${ }^{65}$ On the counteroffensives in July and August 1941, see David Glantz, Barbarossa Derailed: The Battle for Smolensk 10 July-10 September 1941, vol. 1, The German Advance to Smolensk, the Encirclement Battle, and the First and Second Soviet Counteroffensives, 10 July-24 August 1941 (Solihull, 2010), chaps. 5, 9-11, and Glantz, Barbarossa Derailed: The Battle for Smolensk 10 July-10 September 1941, vol. 2, The German Offensives on the Flanks and the Third Soviet Counteroffensive, 25 August-10 September 1941 (Solihull, 2012), chaps. 5-7. On the battle of Kiev, see David Stahel, Kiev 1941: Hitler's Battle for Supremacy in the East (Cambridge, 2012). More generally on the troubles of the German Army in July and August 1941, see also Stahel, Operation Barbarossa and Germany's Defeat in the East (Cambridge, 2009). 
would pull back, blaming them for "excesses." ${ }^{96}$ In 1941/42 we can discern a similar pattern. After his November signal, Stalin returned to the issue of exterminating the enemy in an order to the troops on February 23, 1942. He called the notion "that the Red Army has the goal to exterminate the German people and destroy the German state . . . stupid nonsense and silly slander." Of course, the Red Army "could not have such idiotic goals." The new line was no longer to kill every German found on Soviet soil, but explicitly to take prisoners if they put down their arms. "The Red Army captures German soldiers and officers and saves their lives, if they surrender," the supreme commander claimed, and he continued: "The Red Army destroys German soldiers and officers if they refuse to put down their weapons and [continue] to attempt, gun in hand, to enslave our homeland. ${ }^{967}$

This de-escalation was prompted by the counterproductive results of the escalation speech of November: if the Germans knew they would be shot, they would fight even harder to avoid captivity. This idea was not new to Soviet tacticians, and there had been attempts to encourage Germans to switch sides from the start of the war. But in February 1942 this discourse was significantly reinforced and frontline agitation across the line was stepped up. ${ }^{68}$ Just as importantly, it was flanked by measures to ensure that the friendly words were not met with unfriendly deeds. A month after Stalin's speech, a lieutenant Kurdriavtsev shot a German he was leading away from the front line for interrogation by headquarters. He was arrested and put on trial, and commanders were warned that in similar cases "the most severe measures" would be applied to those responsible. ${ }^{69}$

Thus, while since November 1941 many troops were under the impression that they had orders to shoot prisoners, now the signal had been reversed. By May 1942, captured Soviet officers told their interrogators that "according to a Stalin order of February '42, POWs must no longer be shot and should be treated

${ }^{66}$ The most famous instance is Stalin's March 1, 1930, article, "Dizzy with Success," in which he blamed the "excesses" of collectivization on local officials. Sheila Fitzpatrick, Stalin's Peasants: Resistance and Survival in the Russian Village after Collectivization (New York, 1994), 62-65.

67 "Prikaz narodnogo komissara oborony, 23 Fevralia 1942 g., No. 55," Krasnaia zvezda, February 23, 1942, 1-next to a photograph of Stalin. This was not to be Stalin's last public pronouncement on the POW issue. In order no. 130 of May 1, 1942, he again reminded his soldiers that they should "exterminate the German occupants to the last man, insofar as they do not become prisoners of war" ( poskolko oni ne budut sdavat'sia v plenPravda, May 1, 1942, 1), and on April 2, 1945, the troops were told to "change the attitude towards Germans, be they prisoners of war or civilians" (Stavka directive no. 11055, RA/ VO 5 (4): 221-22).

${ }^{68}$ For material concerning the propaganda for Germans crossing the line, see RA/VO 24 (13-3): 9-143.

${ }^{69}$ Order to the Commanders and Commissars of the units of the 17th Guard Rifle Division, March 27, 1942, BA-MA RW 2/27, fol. 3. 
well." ${ }^{, 70}$ Even mock executions could henceforth lead to a visit by the military prosecutor. $^{71}$

\section{Stalinist De-Escalation}

By the beginning of 1943, then, the most vicious period of shooting POWs was over. A landmark was the detailed order regarding the rules for the evacuation of prisoners from the front line passed by the Commissariat for Defense on January 2, 1943 (no. 001). It built on the Polozhenie o voennoplennykh but also took the experience of the first one and a half years of war into account. ${ }^{72}$ The results can be noted in the files of German units. One careful study of a German infantry division chronicles several cases of immediate execution of German prisoners by the retreating Red Army in 1941 and advancing troops in the winter of 1941/42; but it also mentions that such cases became much less frequent thereafter. ${ }^{73}$ A diarist also noted that while in January 1942 the Red Army "did not waste its time on prisoners," by 1943 "the Russians took many prisoners, they no longer kill them as before." $" 74$

The developments after Stalin's speech of February 1942 represent a process of normalization. Nevertheless, the shooting of POWs did not stop completely. While the reports of German military intelligence henceforth show a more positive picture of the treatment of German POWs in Soviet captivity, they still include examples of executions. ${ }^{75}$ Orders by the Chief of Staff of the Soviet 5 th Tank Army of November 17, $1942,{ }^{76}$ and of the commander of the VIII Cavalry Corps of November 27, 1942, also noted cases of prisoner executions. ${ }^{77}$

${ }^{70}$ Dulag 240, Ic to Kommandierender General der Sicherungstruppen und Befehlshaber im Heeresgebiet Mitte, AO (Abw. III), May 20, 1942, BA-MA RW 2/158, fols. 23-25, at 24 .

${ }^{71}$ Nikolai Litvin, 800 Days on the Eastern Front: A Russian Soldier Remembers World War II (Lawrence, KS, 2007), 126-27 (1945).

${ }^{72}$ BA-MA RW 5/506, fols. 150-54 (German translation).

${ }^{73}$ Christoph Rass, "Menschenmaterial": Deutsche Soldaten an der Ostfront. Innenansichten einer Infanteriedivision 1939-1945 (Paderborn, 2003), 163, 165, 334. This does not mean that the cases stopped completely. In March 1943 the regiment reported that some of their wounded soldiers had their throats slit by Red Army soldiers. Ibid., 335 n. 19.

${ }^{74}$ Willy Peter Reese, Mir selber seltsam fremd. Die Unmenschlichkeit des Krieges. Russsland 1941-44 (Berlin, 2004), 83, 213.

${ }^{75}$ This statement is based on a systematic reading of the files of military intelligence (Abt. Ic) for an army and a division, flanked by a wider reading of Ic records on all levels of the military machine and through the entire course of the war. The two case studies were the Third Panzer-Army (until January 1, 1942: Third Panzer Group; BA-MA RH 21-3) and the 18th Infantry Division (BA-MA RH 26-18). The holdings of the latter stop after 1943, while those of the former continue through February 1945.

${ }^{76}$ BA-MA RH 24-17/200, fol. 54 (and reverse; German translation).

${ }^{77}$ BA-MA RH 24-17/200, fol. 51 (and reverse; German translation). 
Interviews with participants in the Battle of Stalingrad conducted by a commission of Soviet historians immediately after the fighting ended in February 1943 also mention prisoner killings, including cases in which soldiers were offered rewards for bringing in captives but nevertheless preferred to shoot them. ${ }^{78}$ As late as the fall of 1942, the commander of this front, A. I. Eremenko, had answered Zhukov's query about the whereabouts of POWs with a laconic "we shot the prisoners."79 The files of the Wehrmacht's War Crimes Unit, likewise, continue to bulge with reports of prisoner executions throughout 1943 and $1944,{ }^{80}$ and memoirists continue to report executions during the summer of $1942^{81}$ and well into 1944 and $1945 .^{82}$ A captured Soviet doctor went as far as claiming that Stalin's order "to spare surrendering prisoners" was "a complete fiction." 83

A lot depended, as always, on local circumstances and the interpretation of Stalin's de-escalation order. Frontline propaganda frequently stressed the second part of the message (that the Red Army destroyed those who refused to put down their arms) over the first (that the Red Army took prisoners). ${ }^{84}$ Some officers, likewise, interpreted the signal narrowly to mean that Germans who actively

${ }^{78}$ Jochen Hellbeck, Die Stalingrad Protokolle. Sowjetische Augenzeugen berichten aus der Schlacht (Frankfurt, 2012), 199-200, 311, 397-98, 419, 433, 522.

${ }^{79}$ F. I. Chuev, Soldaty imperii: Besedy. Vospominaniia. Dokumenty (Moscow, 1998), 314. For more on prisoner shootings in Stalingrad, see A. E. Epifanow and Hein Mayer, Die Tragödie der deutschen Kriegsgefangenen in Stalingrad von 1942 bis 1956 nach russischen Archivunterlagen (Osnabrück, 1996), 14, 15, 20, 23, 24, 33, 41, 49; and Antony Beevor, Stalingrad (London, 1998), 357, 363, 371, 384, 386.

${ }^{80}$ See, e.g., the series of files BA-MA RW 2/155 through RW 2/162. Note, however, that much of the material contained in these also refers to 1941 and 1942 . There is also a slim file with reports for 1944 and 1945: RW 2/241.

${ }^{81}$ Anonymous, "V boiakh za Rodinu i za Stalina," unpublished memoir, typescript (1951), Bakhmeteff Archive, Columbia University Rare Book \& Manuscript Library (4078290, 12:42w), 226.

${ }^{82}$ Budnitskii, "The Intelligentsia Meets the Enemy," 639-40. Many examples can be found in a large-scale interview project of Soviet veterans, whose transcripts are now available online: "Vospominaniia veteranov Velikoi Otechestvennoi Voiny," http://ire member.ru. For one example pars pro toto, see G. Koifman, interview with A. G. Vesterman (July 17, 2011), http://iremember.ru/memoirs/tankisti/vesterman-arkadiy-grigorevich/. See also the German veterans' memories of near misses or actual executions in 1944 and 1945: Elke Scherstjanoi, Wege in die Kriegsgefangenschaft. Erinnerungen und Erfahrungen deutscher Soldaten (Berlin, 2010), 77-81, 83, 103, 118-19, 183, 217. On Cossacks hacking off the hands of surrendering Germans during the Dnepr-Carpathian Offensive in early 1944: Milovan Djilas, Conversations with Stalin (New York, 1990), 54.

83 "Aufzeichnungen des russ. Kgf., Militärarzt 3. Ranges Bobotscharkij-Jakowlew, Aleksiej Pawlowitsch," BA-MA RW 2/158, fols. 120-23, at 123 (German translation).

${ }^{84}$ Edele and Geyer, "States of Exception," 369. 
deserted to the Soviets should be spared, but those captured by force of arms should be executed on the spot. $^{85}$

Overall, however, the numbers show a clear tendency toward de-escalation. Not only were many more German soldiers captured, but the gap between the number of Germans missing in action and those who, however ragged, hungry, and sick, made it to NKVD reception points started to narrow from only 30 percent in 1941 to 40 percent in 1942, and on to 63 and 83 percent, respectively, in 1943 and 1944 (table 2). From 1943 onward, then, a growing majority of German soldiers captured by the enemy survived the event. ${ }^{86}$

What we can discern, then, is the following dynamic: the fairly frequent, spontaneous killings of POWs during the retreats of 1941 were reinforced both by localized orders and by Stalin's escalation speech of November 6 of that year. His de-escalation order of February 23, 1942, brought the signals from above into line with what the military command had ordered consistently since the start of the war. Together with the changed fortunes of war and the emergence of a more professional, more disciplined army, this coalescence of the pronouncements of all levels of the hierarchy led to a normalization of the treatment of POWs, which made their initial slaughter at the point of capture less likely. ${ }^{87}$

\section{DyNAMICS FROM BELOW}

The interpretation offered thus far destabilizes received historical wisdom. Much of the writing on Soviet war crimes postulates a slow, linear process of barbarization through the encounter with German war making, reinforced by hate propaganda. This theory works quite well when dealing with what happened on German territory in 1945, but it cannot account for the killings under review here, which happened from the outset of the war. Moreover, they show the obverse of

${ }^{85}$ Such an order by a company commander is reported from October 15, 1942. Excerpt from prisoner interrogation, December 29, 1942, BA-MA RW 2/158, fol. 251 (German text).

${ }^{86}$ A study of 150 survivors, who in their overwhelming majority were captured in 1944 and 1945 (mostly by the Soviets), notes that reports of killings upon capture are "rare" in this sample. Dietmar Sauermann and Renate Brockpähler, "Eigentlich wollte ich ja alles vergessen . . ' Erinnerungen an die Kriegsgefangenschaft 1942-1955 (Münster, 1992), 9-10,28.

${ }^{87}$ On the emergence of a new Red Army, see David M. Glantz, Colossus Reborn: The Red Army at War, 1941-1943 (Lawrence, KS, 2005); Walter S. Dunn, Stalin's Keys to Victory: The Rebirth of the Red Army in WW II (Mechanicsburg, PA, 2007); David R. Stone, "Stalingrad and the Evolution of Soviet Urban Warfare," Journal of Slavic Military Studies, no. 22 (2009): 195-207. On the mobilization system more generally, see Roger Reese, Why Stalin's Soldiers Fought: The Red Army's Military Effectiveness in World War II (Lawrence, KS, 2011). 


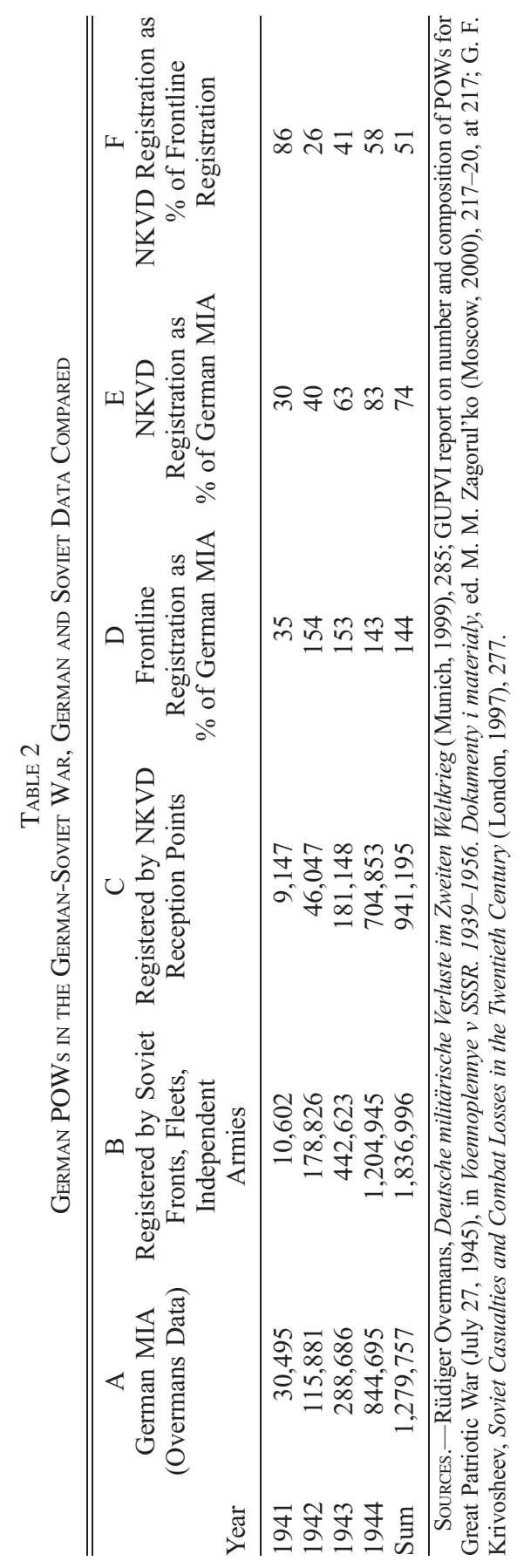


the tendency usually supposed: these killings were there from the start, intensified during the first wartime winter, and then de-escalated. ${ }^{88}$

As we have seen, the lethality of Soviet behavior was the result of a complex dialectic of signals from above and dynamics from below. I will now turn to the latter and attempt to understand the reasons for spontaneous executions at the front line. Some historians, such as Amir Weiner, focus on prior brutalization. Weiner has argued that the Soviet system was marked by "integral brutality," which was "unleashed" at the beginning of the war. His account universalizes ideological warriors, NKVD personnel, and other radicals - groups that Michael Geyer and I have described as the "cadres of totalitarian violence." The example Weiner gives is the communist Zinaida Pytkina, who was interviewed by Laurence Rees in 1998 as part of a BBC production on the war. She had been drafted into military counterintelligence (SMERSh) in 1943, took part in beating POWs during interrogation, and executed one of them with a pistol shot in the neck. Pytkina's story exemplifies one scenario for the killing of German prisoners: execution by police forces once their interrogations were completed and they became, from a completely instrumental perspective, useless and therefore dispensable. ${ }^{89}$ This kind of killing can be traced back to the first days of Soviet power. Its prototype, perhaps, was the execution of the tsarist family, and its most spectacular instances took place during the Great Terror of 1937-38, in the forest of Katyn in 1940, and in the frenzy of executions during the retreat of 1941. It was professional violence, as a rule hidden from sight and not meant as a spectacle. It was, in the words of one historian, a "technique," part of the tool kit of utopian social engineering. ${ }^{90}$

However, NKVD personnel were not the only perpetrators, and the coldblooded shooting after interrogation is only one of many scenarios. Ordinary soldiers, too, executed prisoners, sometimes on orders from their officers, sometimes on their own initiative, and a utopian motivation is at least questionable in these cases. Moreover, as Oleg Budnitskii has pointed out, many of the most

${ }^{88}$ See also Mark Edele, "Learning from the Enemy? Entangling Histories of the German-Soviet War, 1941-1945," in Totalitarian Dictatorship: New Histories, ed. D. Baratieri et al. (London, 2013), 190-211.

${ }^{89}$ Weiner, "Something to Die For, a Lot to Kill For," esp. 101 (for the example); Edele and Geyer, "States of Exception," 350, 365-67; Laurence Rees, War of the Century: When Hitler Fought Stalin (New York, 1999), 165-68, 246.

${ }^{90}$ Stefan Plaggenborg, "Stalinismus als Gewaltgeschichte," in Stalinismus. Neue Forschungen und Konzepte, ed. Stefan Plaggenborg (Berlin, 1998), 71-112, esp. 89-90; Peter Holquist, "State Violence as Technique: The Logic of Violence in Soviet Totalitarianism," in Landscaping the Human Garden: Twentieth-Century Population Management in a Comparative Framework, ed. Amir Weiner (Stanford, CA, 2003), 19-45; Paul Hagenloh, Stalin's Police: Public Order and Mass Repression in the USSR, 1926-1941 (Baltimore, 2009); and David R. Shearer, Policing Stalin's Socialism: Repression and Social Order in the Soviet Union, 1924-1953 (New Haven, CT, 2009). 
ideologically committed individuals resisted unrestrained force, at least in 1945. Budnitskii's examination of the roots of integral brutality focuses less on ideology than on the experiences of the Civil War and the anomie of life in the 1930s - that is, what some historians describe as the Soviet "culture" or even "civilization" of violence. ${ }^{91}$ And, indeed, unlike the NKVD killings discussed by Weiner, the violence of troops has no continuities with the 1930s: these were not shootings behind closed doors, away from the public eye. Instead, they are reminiscent of the graphic violence of the Civil War period, which significant numbers of those fighting could remember personally. By August 1941, individuals whose birth years ranged from 1890 to 1923 were serving in the army, ${ }^{92}$ and in November an NKVD report on the 33rd Army noted that there were "a significant number of soldiers and commanders who have participated in the civil war." ${ }^{\text {"93 }}$ By war's end, indeed, men who were likely to have fought in both the Civil War and the Great Patriotic War constituted nearly 50 percent of the male draft cohorts. ${ }^{94}$ Others had access to such memories secondhand, from stories they had heard, read, or watched in the movies. ${ }^{95}$

Such latencies were reinforced by other structural factors. There was little that was mechanized, distant, or "modern" about much of the fighting in 1941. On

${ }^{91}$ Budnitskii, "The Intelligentsia Meets the Enemy," 646 and passim; Stefan Plaggenborg, "Weltkrieg, Bürgerkrieg, Klassenkrieg. Mentalitätsgeschichtliche Versuche über die Gewalt in Sowjetrußland," Historische Anthropologie, no. 3 (1995): 493-505; Plaggenborg, "Gewalt und Militanz in Sowjetrussland 1917-1930," Jahrbücher für Geschichte Osteuropas 44, no. 3 (1996): 409-30; Bernhard Chiari, "Zwischen Hoffnung und Hunger. Die sowjetische Zivilbevölkerung unter deutscher Besatzung," in Verbrechen der Wehrmacht. Bilanz einer Debatte, ed. Christian Hartmann, Johannes Hürter, and Ulrike Jureit (Munich, 2005), 145-54, esp. 152; Jörg Baberowski, "Zivilisation der Gewalt. Die kulturellen Ursprünge des Stalinismus," Historische Zeitschrift 281 (2005): 59-102; Baberowski, Der Rote Terror. Die Geschichte des Stalinismus (Frankfurt, 2007); Baberowski, Verbrannte Erde. Stalins Herrschaft der Gewalt, 2nd ed. (Munich, 2012).

${ }^{2}$ G. M. Shipshov, "Oni stali osnovnym kontingentom Sovetskoi armii," Voennoistoricheskii zhurnal, no. 3 (2008): 34-35, at 34.

${ }^{93}$ NKVD report from Western Front, November 15, 1941, in Lubianka $v$ dni bitvy za Moskvu, 255.

${ }^{94}$ Mark Edele, "Soviet Veterans as an Entitlement Group, 1945-1955," Slavic Review 65 , no. 1 (2006): 111-37, 113-15, esp. 115 , table 1.

${ }^{95}$ On prisoner executions and graphic violence in the Civil War, see, inter alia, W. Bruce Lincoln, Red Victory: A History of the Russian Civil War 1918-1921 (New York, 1989), 86; Hiroaki Kuromiya, "Donbas Miners in War, Revolution, and Civil War," in Making Workers Soviet: Power, Class, and Identity, ed. Lewis H. Siegelbaum and Ronald G. Suny (Ithaca, NY, 1994), 138-58, at 152; The Complete Works of Isaac Babel, ed. Nathalie Babel (New York, 2002), 292-95, 344-45, 365-61, 415, 441, 446-47, 460; Richard Pipes, Russia under the Bolshevik Regime (New York, 1993), 86. See also Dietrich Beyrau, "Der Erste Weltkrieg als Bewährungsprobe. Bolschewistische Lernprozesse aus dem 'imperialistischen' Krieg,” Journal of Modern European History 1, no. 1 (2003): 96124, esp. 106-7. 
December 5, to quote an extreme example, Red Army infantrymen fighting for the village of Padikovo west of Moscow were ordered into a bayonet attack. Most did not have bayonets, however, so they beat the Germans with their rifle butts instead. Once those broke, they used their fists. ${ }^{96}$ Under such conditions, the policy laid out in the Polozhenie o voennoplennykh, which required soldiers to shift, from one minute to the next, from trying as hard as they could to kill the enemy to giving him shelter, food, and medical care, would have required an extremely high level of discipline.

In 1941-42, however, discipline was frequently replaced by brute force. The 1940 disciplinary regulations gave commanders the right to use whatever means were necessary against their subordinates, including "employing force or weapons." ${ }^{\prime 97}$ And they did use these, from the very beginning. The gun-wielding commander or commissar threatening his soldiers into action is not just a figment of Nazi propaganda - he was a quite real-life figure. ${ }^{98}$ At times, the culture of violence in the Red Army was so flagrant that political workers complained about it in their reports, such as in the case of a regimental commander who beat a subordinate with a rifle butt because the latter had ordered the digging of trenches in the wrong spot. ${ }^{99}$ Nevertheless, the use of violence was supported from on high if it was necessary to ensure that soldiers would fight. "Every day," demanded Mekhlis on July 20, 1941, the ranks must be told that retreat without an order was a crime. In this context he reminded commanders of their right to use their weapon "where this is necessary." "100

Necessary or not, violence by commanders against their own people was a part of life in the Red Army. ${ }^{101}$ Stalin himself complained on October 4, 1941, in an order "on instances of substituting repression for educational work," that commanders shot their underlings "without any reason," that they beat or pistolwhipped them for minor infractions such as smoking at night. ${ }^{102}$ His suggestion

${ }^{96}$ Abakumov to Beriia on situation at Western Front, not before December 11, 1941, Lubianka v dni bitvy za Moskvu, 285; see also ibid., 298.

${ }^{97}$ Aleksandr Alekseevich Pechenkin, "Byla li vozmozhnost' nastupat'?" Otechestvennaia istoriia, no. 3 (1995): 44-59, at 48-49; RA/VO 17-6, 325 n. 11. 87.

${ }^{98}$ Glantz, Collossus Reborn, 585; Edele and Geyer, "States of Exception," 364, 386-

${ }^{99}$ Excerpt of political report of 186th Rifle Division, September 25, 1941, contained in Files of Generaloberkommando XXIII Armeekorps, Abt. Ic, BA-MA RH 24-23/239, fol. 26 (German translation).

${ }^{100}$ Files of Wehrmachtsführungsstab, BA-MA RW 4/329, fols. 17-21, at 20 (German translation).

${ }^{101}$ On Zhukov's and Kulik's brutality: Viktor Cherepanov, Vlast $i$ voina. Stalinskii mekhanizm gosudarstvennogo upravleniia v Velikoi Otechestvennoi voine (Moscow, 2006), 486-87.

${ }^{102}$ Order no. 0391, signed by Stalin and Shaposhnikov, in RA/VO 13-2 (2): 108-9. 
instead to "educate" subordinates often fell on deaf ears. ${ }^{103}$ In early 1942, Vasilii Grossman described a Colonel Pesochin in his diary. "Big and fat," he "punches his subordinates in the face with his fist," and they in turn passed on the compliment to their subordinates, a "chain of command of punching." "The political officer of a company repeatedly complained in his diary of June and July 1942 about a lack of discipline that was replaced by violence from the command staff. He did not approve of such abuse and tried to fight it by threatening the abusers in turn. ${ }^{105}$ Violence within the Soviets' own ranks was also institutionalized in the blocking detachments, which existed well before Stalin's 1942 order. ${ }^{106}$ Sometimes soldiers and commanders would not take it any more. In 1941, some soldiers shot their officers, or officers shot the commissars who tried to get them to fight. ${ }^{107}$ Most of these cases probably went undetected at the front line, but by June 1942, the Soviet authorities knew of sixteen such occurrences and had punished twenty-four families in lieu of the perpetrators. ${ }^{108}$ Given this atmosphere of violence, abuse, and neglect in the Red Army, should we be surprised if enemy captives were not treated with much concern?

Military necessity added further incentives to make short work of POWsindeed, this may have been the strongest motivation. Retreating troops who have taken prisoners have three options: take them along, which causes additional strain, particularly if the retreat is a quick one; release them, which puts the retreating group in danger and returns fighters to the enemy; or kill them, which might seem like the most obvious option. The choice might have been fairly straightforward for people who had lived through the violence of Stalinism. In

${ }^{103}$ See order no. 0029 of commander of southwestern front, Bodin, on lack of implementation of Stalin's order no. 0391 (December 12, 1941), in Skrytaia pravda voiny. 1941 god: neizvestnye dokumenty, ed. P. N. Knyshevskii et al. (Moscow, 1992), 311-12.

104 Antony Beevor and Luba Vinogradova, eds., A Writer at War: Vasily Grossman with the Red Army 1941-1945 (London, 2006), 69-70.

${ }^{105}$ Files of 297, Infantry Division, Ic, BA-MA RH 26-297/100 (unpaginated; German translation).

${ }^{106}$ Blocking detachments were units deployed by the Soviets behind their own lines to prevent unauthorized retreat and desertion from the field of battle. A. A. Maslov, "How Were Soviet Blocking Detachments Employed?" Journal of Slavic Military Studies 9, no. 2 (1996): 427-35, at 427-28; Vladimir Daines, Shtrafbaty i zagradotriady Krasnoi Armii (Moscow, 2008); Alexander Statiev, "Blocking Units in the Red Army," Journal of Military History 76, no. 2 (2012): 475-95.

107 Berkhoff, Harvest of Despair, 13. On soldiers shooting the politruk or their officer before going over to the enemy, see also Generalkommando XXVI. Armeekorps, "Tätigkeitsbericht Ic, 1.6.1941-20.8.1941," BA-MA RH 24-26/125, fol. 15; BA-MA RH 24-17/ 152, fol. 31 (report on prisoner interrogations, XVII Army Corps, July 2, 1941, German original); on such moods expressed but not acted upon, see report on "anti-commander moods" in the Baltic fleet (September 11, 1941), in Skrytaia pravda voiny, 273-74.

${ }^{108}$ Beria to Stalin, June 18, 1942, reprinted in Lubianka, Stalin i NKVD-NKGB-GUKR SMERSh. 1939-mart 1946, 349-50, at 349. 
1937 and 1938 Soviet citizens had been shot by their own government for the mere suspicion of being enemies. It may not be too astonishing that, once put into a position to decide about life and death themselves in a context where their own lives counted for little, some of the survivors of the Great Purges would decide to shoot those clearly marked as enemies and behaving as such. One such incident was recorded by the chief of the reconnaissance unit of the Staff of the 33rd Army, Captain Potapov, in early December 1941: "100 POWs, made by the 1st GSMD [Guards Motorized Rifle Division], were shot in view of the complicated situation, on order of the Division Commissar."109 In another instance, "we took a seriously wounded soldier captive," reported the Chief of Staff of the 636th Rifle Regiment in February 1942, "who on the way, in view of his serious wound, was bayoneted by Senior Seargeant Kabulov." ${ }^{110}$ Reconnaissance units made short work of "tongues"- prisoners who had been taken behind enemy lines for interrogation - if they proved too much trouble on the way back; in such cases the survival of the group would take precedence. "After taking one German captive, we began to drag him toward our lines. But he, afraid of captivity, resisted seriously," reported an officer of the 46th Cavalry Division in his description of his group's mission, concluding, "Abaev decided to shoot him."111 In August of 1942, the head of the reconnaissance unit of the 33rd Guards Rifle Division wrote to the 62nd Army that a captured enemy was interrogated and then "shot because of a heavy wound," as it was impossible to evacuate him behind the lines. ${ }^{112}$

Executions for a variety of pragmatic reasons continued throughout the war. For example, even once the tide of war had turned, local counterattacks could throw advancing units back, leading to situations like the one described in a short report radioed in March 1944:

\section{5 hours $2300 \mathrm{khz} \quad$ Kashmat and Szesda $\quad 27.3 .44$}

One of our little sisters has reached the train station and found there soldiers in all the houses - Germans, Romanians, and Yugoslavs. They were interrogated briefly. They did not have any documents on them. They said that they were part of the 32nd Div. These are newly arrived forces. The enemy was first surprised, then raised the alarm and resisted strongly. Ours had to retreat. The prisoners were shot. ${ }^{113}$

109 "Spravka" (December 8, 1941), BA-MA RW 2/154, fol. 145.

${ }^{110}$ Original trophy document, BA-MA RW 2/158, fol. 17. Photocopy also contained in RW 2/152, fol. 6.

${ }^{111}$ Diary entry for November 25, 1941, BA-MA RW 2/158, fols. 197-213, at 199 (Russian original).

${ }_{112}$ Photocopy of trophy document, BA-MA RW 2/153, fol. 189 (Russian original).

${ }^{113}$ Report on overheard radio message. Army Group Wöhler to OKH, April 12, 1944, BA-MA RW 2/155, fol. 70 (translation from the German). Underlining in source. 
In other cases, quick advances could cause problems not dissimilar to those that accompanied retreats. In the summer of 1944, for example, the day after a fortykilometer march, the divisional commander asked Nikolai Litvin and his comrade Sashka to "deal with the prisoners at our own discretion. ... I understood this to mean that the prisoners were marked for execution." 114

And finally, revenge - one of the central passions of war - completed the toxic mix. Revenge killings could be quite abstract, punishing any enemy body available for the atrocities of the opposing side. "I saw in front of me a man who could have killed my relatives," to quote Pytkina's recollection of her state of mind when fulfilling the order to "sort out" a prisoner after interrogation. ${ }^{115}$ At the time she killed her prisoner, she had ample reason to be angry_-by 1943 the horror of the German way of war had become clear enough. That atrocities would be committed was a conviction the propaganda organs disseminated from the first days of the war. On June 26, 1941, Krasnaia zvezda opened with a large headline about the "fascist barbarians" who came to trample on Soviet soil. As there was not yet much material about the "unheard-of misdeeds" of these "brutish bands," the paper had to go back to 1939 — when (as part of the Hitler-Stalin pact, ironically) the Soviets had taken over a city the Nazis had occupied just before them - in order to find some "brutality" (zverstvo) to report on. The writer and journalist Ilya Ehrenburg, who would become the most prolific and popular hate propagandist of this war, drew on what he had seen in the Spanish Civil War to the same end. ${ }^{116}$ As time went on and material accumulated, real-life stories were written into this preconceived narrative. As Mekhlis summarized the "experience of the first weeks of war" on July 15, it was essential to "highlight the atrocities the fascists commit toward POWs, the peaceful [civilian] population, [and] the families of commanders and men." Such propaganda was to "develop among the troops the desire to take revenge for the atrocities, for the death of our people, for the tears and the suffering of the peaceful population and the families of servicemen." $" 117$

The Germans, of course, made the work of the propagandists easy enough. Ten days after this directive was issued, Krasnaia zvezda could already report on the shooting and hanging of women and children, the burning of civilian men, the torture of POWs, and the victimization of wounded Red Army men - and it promised revenge. ${ }^{118}$ Although official policy proclaimed captivity an act of

${ }^{114}$ Litvin, 800 Days, 80.

${ }^{115}$ Rees, War of the Century, 167.

116 "Verlomnyi vrag vstupil na zemliu nashei Rodiny . . ," and "Grozen gnef naroda," both Krasnaia zvezda, June 26, 1941, 1; V. I'enkov, "Zverstva fashistskikh razboinikov," and I'lia Erenburg, "Gitlerovskaia orda," both in ibid., 3.

117 RA/VO 17-6 (1-2): 442-44, at 443.

118 "Otomstim fashistskim izvergam za zverstva nad nashimi liud'mi," Krasnaia zvezda, July 25, 1941, 1. 


\section{Edele}

desertion, the existence of Soviet POWs was not denied. Instead, it was integrated into the atrocity propaganda. Among the first three booklets in the series "Aid for the Propagandist and Agitator" was the title Fascist Brutality toward POWs (July 2, 1941); ${ }^{119}$ the slogans distributed on July 12 for use in agitation work among the troops included the claim that "the fascist barbarians torture and bestially murder prisoners of war"; ${ }^{120}$ and on October 16, 1941, Krasnaia zvezda published its first detailed report on conditions in German POW camps. ${ }^{121}$ Particularly powerful were excerpts from trophy documents taken from German soldiers, particularly if they detailed war crimes against civilians. ${ }^{122}$ Knowledge of the existence of the German "Commissar Order," reported as an order either to shoot all prisoners or all officers, ${ }^{123}$ was systematically disseminated through the network of frontline newspapers, individual broadsheets, and agitators embedded in the army. On December 10, 1941, Mekhlis ordered that an article in that day's issue of Krasnaia svezda be used in frontline agitation. ${ }^{124}$ Entitled "The Germans Shoot Captured Red Army Men," it presented evidence for German atrocities toward POWs. Like Stalin's earlier speech, it did not explicitly state that the Red Army would no longer give quarter; but soldiers would have needed to read very carefully and with a very level head not to get that message:

With such an enemy there can be only one conversation - by the bullet. Toward such an enemy there cannot be any compassion, any leniency. ... .

... We answer blood with blood, death with death. Three arshins of earth, that's all any German will receive from us.

The Germans wanted a war of extermination. They have got it. ${ }^{125}$

This evolving discourse was embedded into a thick conversation of rumors, reinforcing and furthering it. ${ }^{126}$ When in September 1941 Red Army men beat surrendering Germans with their fists before shooting them, their commander

$119 \mathrm{RA} / \mathrm{VO} 17-6(1-2): 32$.

${ }^{120} \mathrm{RA} / \mathrm{VO} 17-6$ (1-2): 36-38, at 37.

121 "Uzhasi fashistskogo plena. Rasskaz starshego politruka Gorshenina," Krasnaia zvezda, October 16, 1941, 3.

${ }^{122}$ For example, "Dokumenty o krovozhagnosti faschistskikh merzavtsev," Krasnaia zvezda, October 29, 1941, 3 .

${ }^{123}$ For example, see the recollections of V. Valentinov, "Wie ich 'Kollaborateur' wurde," Bakhmeteff Archive, Columbia University Rare Book \& Manuscript Library (4078221, 12:42w), 5 .

${ }^{124}$ L. Mekhlis, directive of December 10, 1941, to disseminate article from Krasnaia zvezda of the same date, reprinted in RA/VO 17-6 (1-2): 91.

125 "Rasstrely nemtsami plennykh krasnoarmeitsev," Krasnaia zvezda, December 10, 1941. (One arshin equates to $71 \mathrm{~cm}$.)

126 "Conversation of rumors" is Sheila Fitzpatrick's term. See her Stalin's Peasants, chap. 11. 
wanted to know why they had ignored direct orders to take prisoners that had been issued before the battle. He learned that they had met military scouts from their home town who had told them about German executions of prisoners. They might not have believed the agitators, their superior mused, but they took seriously what they were told by soldiers from their own town. ${ }^{127}$ Others also cited their knowledge of what the Germans would do to Soviet prisoners as a reason to proceed likewise. "Do you want us to feed the prisoners with our bread," rhetorically asked a probably hungry political officer confronted with questions by a commander about his deeds, "when at the same time the Germans kill our prisoners?"'128

Often enough, mediated knowledge of enemy atrocities only formed the backdrop to real encounters, and sometimes revenge may even have been meted out to the real culprits. In December 1941, a Soviet officer of the 46th Cavalry Division described the results of the retreating enemy's scorched-earth tactic in his diary: most villages were completely burned to the ground. The next day, on December 24, his men caught three "Fritzes"-_"probably arsonists," he noted with satisfaction. "Two of them we shoot without interrogation, one we send under escort to Division HQ. . . . On the way . . . the local population reckoned with him for everything." ${ }^{\prime 29}$ While here the guilt of the Germans was simply assumed, in other cases it had been observed. ${ }^{130}$

At times, any enemy at hand would do to stand in for the absent object of anger. In January 1943, for example, in the vicinity of Stalingrad, a young German captive became the object of Soviet soldiers' rage. Initially, young Willie had been treated exceptionally well. His captors had adopted him as a surrogate son, shared their food and lodgings with him, and took him along as some kind of mascot. Soon, however, the unit happened upon the remains of the members of a reconnaissance unit that had gone missing. They had been caught by the Germans and stripped naked before being doused with water. Standing next to these human icicles, the soldiers pledged revenge-and administered it immediately. Willie, until then treated like a comrade and fellow human, was now subjected to the same torturous execution as the Soviet scouts before him. His body became the surrogate, the symbol for the absent perpetrators of the original crime. ${ }^{131}$

${ }^{127}$ Valentinov, "Wie ich 'Kollaborateur' wurde," 31, 33.

${ }^{128}$ Protocol of interrogation (Russian original), August 15, 1942, BA-MA RW 2/158, fol. 138. German translation also contained in RW 2/213, fol. 302.

${ }^{129}$ Diary entries for December 23 and 26, 1941 (Russian original), BA-MA RW 2/158, fols. 197-213, at 203.

${ }^{130}$ For an example from the summer of 1944, see Litvin, 800 Days, 70.

${ }^{131}$ Vladimir Tendriakov, "Liudi ili neliudi," Druzhba narodov, no. 2 (1989): 114-44, at $114-17,122-25$. 


\section{FREQUENCY}

Context thus mattered. Depending on the circumstances of a German's capturein the morning or at night, at the beginning or end of a battle, in a small or a large group, after the death of a close comrade or friend of the man who took him captive, in a section of the front where officers had ordered their men to take no prisoners or in another where others had asserted the obverse policy-his chances of survival and evacuation to the rear varied. ${ }^{132}$ If he did not survive, it could be for more than one reason. A low level of training and discipline, military necessity, callous instrumentalism, atrocity propaganda, observable real deeds of the enemy, and what one could hear from other citizens - all could raise the tides of prisoner executions. Escalation and de-escalation brought about by more or less strong signals from above and occasional direct orders could make the waves swell or subside.

But such Braudelian metaphors tell us nothing about the frequency of this phenomenon. How often did the execution or even the mutilation of prisoners happen? Hard numbers are impossible to come by, and those we have pose a variety of interpretive challenges. One approach is to compare German estimates with Soviet tallies. ${ }^{133}$ As of September 1, 1941, the Germans were missing around 20,000 of their men in the East. The military leadership calculated that perhaps a third of them had actually perished, which led them to believe that there should be "13-14,000 German soldiers in Russian captivity." 134 Meanwhile, NKVD reception points had registered 5,093 POWs - at best, 39 percent of the German estimates. ${ }^{135}$ Of course, some POWs might still have been on their way to the reception points, but even by year's end only 9,147 had arrived, still leaving 30 percent of the September number unaccounted for, to say nothing of those taken since then. ${ }^{136}$

${ }^{132}$ Karner, Im Archipel GUPVI, 11. See also interrogation protocol of member of 222nd Soviet Rifle Division, March 26, 1944, BA-MA RH 21-3/512, fol. 42 (German original).

${ }^{133}$ See Rüdiger Overmans, "Das Schicksal der deutschen Kriegsgefangenen des Zweiten Weltkrieges," in Der Zusammenbruch des Deutschen Reiches 1945. Die Folgen des Zweiten Weltkrieges, ed. Rolf-Dieter Müller (Munich, 20008), 379-507, esp. 403.

${ }^{134}$ L. P. Chef-Abt. Gruppe II. "Aktennotiz. Behandlung der Kriegsgefangenen in Rußland” (16.9.41), BA-MA RW 6/279, fol. 15.

135 “'Obzor deiatel'nosti frontovykh organov GUPVI NKVD SSSR v period Velikoi Otechestvennoi voiny" (no later than June 20, 1951), in Voennoplennye v SSSR 19391956. Tom 4: Glavnoe Upravlenie po delam voennoplennykh i internirovannykh NKVDMVD SSSR 1941-1952, 139-81, at 148.

136 "Dokladnaia zapiska uchetnogo otdela 1-go Upravleniia GUPVI NKVD SSSR rukovodstvu Upravleniia ob itogakh raboty za period s 1941 g. po ianvar' 1945 g," (February 5, 1945), in Voennoplennye v SSSR 1939-1956. Tom 4: Glavnoe Upravlenie po delam voennoplennykh i internirovannykh NKVD-MVD SSSR 1941-1952, 197-201, at 197. 
There are three sets of numbers that can be compared: German estimates of men missing in action (MIA), the data produced by Soviet frontline units, and the numbers registered by the NKVD once the POWs had been handed over by the army at collection points (table 2). A simple way to read this table would be to treat the gaps between the three data sets as the number of prisoners who perished or escaped at each point in the process: column D would show the share of those missing in action who were actually taken prisoner, and any shortfall would include those who died of battle wounds or exposure as well as those who had been shot; column E would show the percentage of German MIA who made it beyond the front line to NKVD registration points, any shortfall now including people who died, escaped, or were killed between capture and handover to Stalin's police; and column F would tally the proportion of those who made it from the front line to the NKVD. However, with the exception of 1941, frontline units consistently reported more POWs than the Germans had thought were missing in action; meanwhile, the NKVD numbers consistently trailed behind the German MIA numbers (compare table 2, cols. A and C). A likely explanation is that frontline units, continuously badgered to take prisoners from early 1942, overreported the number they had taken. In 1941, when messages from above were much more mixed, there appears to have been less overreporting. During this first six months of the war, the frontline numbers and the NKVD figures are in the same ballpark, with only a 14 percent difference. Given that this is the period of the most ambiguity and the most widespread reports of prisoner killings, this relatively small discrepancy is remarkable. The difference between the German estimates and the NKVD numbers, however, is much more dramatic, with only 30 percent of the German MIA arriving in the hands of the police forces. The missing 70 percent must include a large number who, in the chaos of 1941, died or disappeared for all kinds of reasons: it is unlikely that in the context of a fighting retreat so many more POWs would have been killed at the front line than while being evacuated behind the lines. Nevertheless, 1941 was clearly an anomalous year. From 1942, with a clearer policy now in place, the percentage arriving in NKVD collection points steadily increased. Overall, for the entire period 1941-44, the proportion of missing Germans who might have perished before registration in NKVD reception points is just over a quarter (26 percent). ${ }^{137}$

${ }^{137}$ Various casualty numbers for the entire cohort of POWs taken from 1941 to 1945 circulate in the literature. Christian Gerlach and Nicolas Werth claim that the number was "perhaps as high as 275,000 to 550,000" ("State Violence-Violent Societies," in Beyond Totalitarianism, 133-79, at 170). Karner estimates between 250,000 and 300,000 (Problemy voennogo plena, 29), a number that already constitutes a retreat from his earlier guesses of "up to 40 percent" and "between half a million and a million" (Karner, Im Archipel GUPVI, 14, 178), a number in turn lower than "more than one million" who are "missing" according to Klaus-Dieter Müller, "Deutsche Kriegsgefangene. Anmerkungen zum Stand der Forschung und den zukünftigen Perspektiven," in Sowjetische und deutsche 
However, this number is no more than an upper limit: not all who died before registration as POWs were shot, let alone mutilated and tortured by their captors. There were a variety of reasons for the extreme levels of mortality: many of the wounded died before they could be taken prisoner or before they reached registration points, some killed themselves to avoid falling into Soviet hands, many froze to death on the battlefield or during their evacuation behind the lines, and still others fell victim to shelling or bombardment from their own side. ${ }^{138}$

Historians working only with the archives of the German War Crimes Unit are easily led astray by the density of the material in those files. But even those data do not imply that most prisoners were shot. Between June 22 and 30, 1941, the Germans were able to document forty-five cases of prisoner execution. Even if we take all of them at face value (which, for reasons noted below, we might not want to do), these would represent five cases per day on the largest front in human history, during an extremely mobile and chaotic kind of warfare. ${ }^{139}$

Working with the holdings of divisions, corps, or armies further supports this diagnosis: cases of prisoner executions are fairly rare in the reports of counterintelligence, which had, among other duties, the task of documenting and reporting enemy atrocities. For example, the 3rd Panzer Army (Panzerarmeeoberkommando 3, formerly the 3rd Panzer Group), part of Army Group Center, reported for the period from late August 1941 until February 10, 1942, the following cases of war crimes (Völkerrechtsverletzungen) by the enemy:

1. End of August 1941: cruel murder of prisoners, eyes stabbed out.

2. October 10, 1941: murder of one Officer and 24 ranks, members of the 7th Tank Div., by shooting.

3. October 17, 1941: extermination [Vernichtung] of an ambulance car by a Russian tank.

4. October 18, 1941: murder of ca. 34 prisoners, members of the 14th motorized infantry division, by bayonet stabs. One case of stabbed eyes.

Kriegsgefangene in den Jahren des Zweiten Weltkriegs, ed. V. Selemenev et al. (Dresden, 2004), 292-351, at 292. Müller's tally is a reassertion of German guesses from the 1960s, which were based entirely on reports by returning POWs and should hence be discarded as useless. See Kurt W. Böhme, Die deutschen Kriegsgefangenen in sowjetischer Hand. Eine Bilanz (Munich, 1966), 125, 151 (1.1 million); on the methodology: 106-10 and 151.

${ }^{138}$ See Overmans, "Das Schicksal der deutschen Kriegsgefangenen des Zweiten Weltkrieges," 403-4; Karner, in Problemy voennogo plena, 18; Hilger, Deutsche Kriegsgefangene, 57-58. See also Hellbeck, Stalingrad Protokolle, 136.

${ }^{139}$ Oberkommando der Wehrmacht (WR). Wehrmacht-Untersuchungsstelle für Verletzungen des Völkerrechts: "Kriegsverbrechen der russischen Wehrmacht, Band 2" (March 1942), BA-MA RW 2/149, fol. 4. The size of the holdings is also misleading insofar as some reports appear again and again in file after file. See, for example, the interrogation protocol about a supposed Stalin order to shoot prisoners, March 7, 1942, BA-MA RW 2/ 154, fol. 171; also contained in RW 2/213, fol. 185; and RW 2/152, fol. 76. 
5. January 10, 1942: murder of 3 German prisoners, members of the 14th motorized infantry division, by shooting.

6. January 22, 1942: 4 German prisoners hung upside down by their feet, heads split or cut off, torsos slit open. Heart, liver and lung reportedly eaten by the Bolshevists [sollen von den Bolschewisten gefressen worden sein]. ${ }^{140}$

If we take all these cases at face value, we are dealing here with six cases within the operating region of a tank army over the period of over five months, involving some seventy victims. Thus, atrocity propaganda notwithstanding, these were far from daily occurrences. Moreover, some skepticism is in order for most of these alleged instances of enemy barbarity. In the first case, the only evidence cited was the statement of the German soldier who found the corpses; ${ }^{141}$ in the fourth case, the evidence was, likewise, the corpses, which were subjected to "detailed examinations"; ${ }^{142}$ for the fifth case, no further evidence is cited in the file. The most colorful final case, where "the Bolshevists" had eaten, in the manner of animals (fressen), the organs of decapitated Germans hanging upside down like cows in a slaughterhouse, must probably also be taken with a grain of salt. The evidence here was the interrogation of a Soviet prisoner, and no German had seen the corpses. The story became more elaborate as time went on. On January 10, 1942, Counter Intelligence (Abt. Ic) reported that, according to an interrogated prisoner, three German prisoners had been denounced as arsonists by a local and were then shot on the order of "a commissar." Twelve days later, on January 22, 1942, the same incident suddenly included mutilation and cannibalism. ${ }^{143}$ Less skepticism might be in order for the second case, which was reported by a soldier who was part of the group and witnessed the shootings (by machine gun) but escaped. Given that he was picked up very soon thereafter by counterattacking German forces, these executions likely happened in the context of retreat and a perceived impossibility of taking along the POWs. ${ }^{144}$ The third case, when a tank ran over an ambulance, possibly killing one heavily wounded man, was also witnessed directly. ${ }^{145}$

If we take only these latter cases that were witnessed by men not under pressure to cater to their interrogators' fantasies, we would be dealing only with two incidents involving twenty-five victims. How rare such cases were becomes clear

140 BA-MA RH 21-3/743, fol. 216.

141 "Vernehmungsprotokoll," September 12, 1941, BA-MA RH 21-3/743, fol. 218 (German text).

${ }_{142}$ Report of November 1, 1941, BA-MA RH 21-3/743, fol. 221.

${ }^{143}$ BA-MA RH 21-3/743, fols. 222, 223.

${ }^{144}$ Report of October 16, 1941, BA-MA RH 21-3/743, fol. 219, and Vernehmungsprotokoll, October 11, 1941, ibid., fol. 219 (reverse).

${ }^{145}$ Report of October 23, 1941, BA-MA RH 21-3/743, fol. 220. 
when we compare their frequency to overall losses. In the case of Panzeroberkommando 3, this exercise is difficult because loss statistics for the period August 1941 through February 1942 are absent from the archival holdings, so we must move to a second case study.

The 18th Motorized Infantry Division fought as part of Army Group North in 1941. In its approximately half year of fighting, it noted eight victims of "Bolshevik atrocities": on June 27-28 there were reports of five killed German POWs and one mutilation of a wounded man; on July 2 they found a dead German, presumably stabbed with his own sidearm; and on August 26 there was an air attack on an ambulance. ${ }^{146}$ During the same period, the division had a total of 5,702 "bloody losses" (dead, wounded, missing in action), including 207 missing. If we assume, for the sake of argument, that $(a)$ all those missing were captured and $(b)$ the seven victims were indeed POWs who had been killed, the total number of potential POWs would have been 214. In this case, 3.3 percent of POWs were liquidated by the enemy. This share is not statistically insignificant, but it hardly amounts to a majority of cases. During the same time period, the division also lost 947 men due to illness ("abtransportierte Kranke"), which means that 135 times more people were evacuated because they had contracted diseases than were killed in a criminal manner by "the Bolsheviks." 147 The overall numbers paint a similar picture. "Several thousand" instances of prisoner killings were documented by the Wehrmacht War Crimes Unit. ${ }^{148}$ This order of magnitude compares to 2.4 million Germans taken captive throughout the war. ${ }^{149}$

We can divide the victims into five groups. First came those who had been shot at or directly behind the front line, a number impossible to reconstruct. ${ }^{150}$ Second were those who died between capture and delivery to POW camps, for reasons ranging from exposure or wounds to accidents, friendly fire, or executions by their captors or by the civilian population. As discussed above, together with those shot at the front line, this group did not exceed 26 percent of German MIAs in 1941-44. This share also includes the third cohort: those who were picked up by the NKVD as spies or enemies and therefore never made it to the POW camps but instead were interrogated in prisons behind the front line and then shot. We

146 18. Infanterie Division (mot.), Abt. Ic, “Tätigkeitsbericht vom 26.5.-31.12.1941," BA-MA RH 26-18/55 (unpaginated file).

${ }^{147}$ Data are from "Kriegstagebuch der 18. Inf. Div. (mot), Führungsabteilung, 25.5.1941-31.12.1941," BA-MA RH 26-18/10, at 267-68.

${ }^{148}$ de Zayas, Die Wehrmacht-Untersuchungsstelle, 284.

${ }^{149}$ Hilger, Deutsche Kriegsgefangene, 71.

${ }^{150}$ One source claims that "up to 958" were shot at the front line in 1941-42 (Petrov, "Vnesudebnye repressii," 77-78), but this claim must be based on faulty note taking. The footnote leads to Konasov, Sudby nemetskikh voennoplennykh v SSSR, 9-10, which in turn quotes de Zayas to the effect that "up to 95\%" died either at the front line, during transport, or later in captivity. 
are dealing here with a maximum of 600 in $1942 .{ }^{151}$ Fourth were those who did make it to the camps, but died subsequently, mostly as a result of the harsh living conditions, poor nutrition, and hard labor. Overall, the Soviets counted 2,388,443 German prisoners throughout the war, of whom 356,687 died in captivity (15 percent). ${ }^{152}$

\section{COMPARISON}

There are thus both similarities and differences between the way the Red Army and the Wehrmacht treated their POWs. Both sides shot some of their prisoners; both sides exploited their labor; both sides at times tried to recruit some of the enemy's troops for their own cause; and on both sides appalling numbers of war prisoners died of malnutrition, disease, and overwork. Both sides, finally, actively brutalized their troops through propaganda. Official discourse on both sides expected enemy atrocities from the very start, well before they had any evidence for these expectations. Both sides had a history of such victimization fantasies. ${ }^{153}$

But here is where the similarities end. ${ }^{154}$ The Germans had a policy of shooting certain categories of prisoners; the Soviets did not. Isolated orders to give no quarter and toleration of murder do not constitute a policy of extermination, nor does atrocity propaganda, even if all of these contribute to the actual killing of actual human beings. The constant orders to take prisoners, and the occasional prosecution of those who did not, have to be seen as part of the official stance as much as the negative utterances and acts. ${ }^{155}$ In their war planning the Germans callously projected the deaths of large numbers of prisoners and civilians and passed regulations mandating a maximum food allowance for enemy prisoners; ${ }^{156}$ the Soviets put together an administration for POWs and established guidelines attempting to keep them alive for use as slave labor. The death toll of 15 percent in Soviet camps is certainly appalling, especially compared to the perhaps 4 to 5 percent of British or American POWs who died in German captivity. But it is

${ }^{151}$ Petrov, "Vnesudebnye repressii," 80.

${ }^{152}$ Hilger, Deutsche Kriegsgefangene, 71.

${ }^{153}$ Vejas Gabriel Liulevicius, War Land on the Eastern Front: Culture, National Identity and German Occupation in World War I (Cambridge, 2000), chap. 7; Enzo Traverso, The Origins of Nazi Violence (New York, 2003), 104; Robert Gerwarth, "The Central European Counter-Revolution: Paramilitary Violence in Germany, Austria and Hungary after the Great War," Past and Present 200 (2008): 175-209; Alexander B. Rossino, Hitler Strikes Poland: Blitzkrieg, Ideology, and Atrocity (Lawrence, KS, 2003); Jochen Böhler, Auftakt zum Vernichtungskrieg. Die Wehrmacht in Polen 1939 (Frankfurt, 2006); Fremde Heere Ost, "Erfahrungen aus dem finnish-russischen Krieg," BA-MA RH $19 \mathrm{II} / 357$, fols. 8-13, at 13.

${ }^{154}$ See Gerlach and Werth, "State Violence-Violent Societies," 171.

${ }^{155}$ See Overmans, "Das Schicksal," 404.

${ }^{156}$ Streit, Keine Kameraden, 67-82, 137-44. 
considerably better than the 27 percent of Americans, Australians, British, Canadians, Dutch, and New Zealanders who perished in Japanese camps. ${ }^{157}$ And no other example in this war could compete with the German treatment of Soviet POWs, which resulted in the deaths of between 43 and 63 percent. ${ }^{158}$

Thus, the comparison of the Soviets with the most genocidal regime of the twentieth century is misleading. Killing unarmed prisoners is a fact of war in many contexts, and the twentieth century was no exception. That the international rules of warfare forbid such acts is itself proof for the likelihood of their occurrence. The Russian Civil War's brutality has already been mentioned, but the Western Front of World War I also saw the emergence of a distinct culture of giving no quarter on both sides of the trenches. In the Pacific theater of World War II, Australians and Americans executed enemy captives, sometimes as part of gruesome rituals such as the collection of ears and noses or the boiling of skulls to send home, signed, to sweethearts or parents. As the Allies fought their way through Western Europe at war's end, they too broke the rules of warfare. The enemy who, overwhelmed, put up his hands in desperation, should not be spared, General Patton advised his soldiers who were about to invade Sicily. "That bastard will die! You must kill him! Stick him between the third and fourth ribs. . . . Stick them in the liver." ${ }^{159}$ When the 2nd Armored Division, known as "Hell on Wheels" and once commanded by Patton, took German POWs in 1945, the Americans marched them to the Soviet lines, according to one survivor, shooting stragglers in their wake. "Well, that's when we definitively lost our illusions about American captivity," he mused. ${ }^{160}$ While such excesses were

${ }^{157}$ Rafael A. Zagovec, "World War II-Eastern Front," in Encyclopedia of Prisoners of War and Internment, 2nd ed., ed. Jonathan F. Vance (Millerton, NY, 2006), 458-61, at 458; Robert S. La Forte, "World War II-Far East," in ibid., 462-64, at 462, 464.

158 The estimate that 15 percent of POWs died in Soviet captivity is based on archival numbers (see above). Also circulating in the literature is the figure of 35 percent, which is based on 1960s estimates deriving from Soviet propaganda reports and reports of survivors. Böhme, Die deutschen Kriegsgefangenen, 151 (numbers), methodology: 3-50, 10610,151 . For death rates in Germany various estimates are available. See the discussion in Hartmann, Wehrmacht im Ostkrieg, 568 n. 3 (43-61 percent); and Hans-Adolf Jacobsen, "Kommissarbefehl und Massenexekutionen sowjetischer Kriegsgefangener," in Anatomie des SS-Staates, ed. Hans Buchheim et al., 5th ed., (Munich, 1989), 2:137-65, at 165 (63 percent).

${ }^{159}$ John Keegan, The Face of Battle (London, 1978), 47-49; John W. Dower, War without Mercy: Race and Power in the Pacific War (New York, 1986); Ferguson, The Pity of War, chap. 13; Niall Ferguson, "Prisoner Taking and Prisoner Killing: The Dynamics of Defeat, Surrender and Barbarity in the Age of Total War," in The Barbarization of Warfare, 126-58 (Patton quotation: 153); Joanna Bourke, An Intimate History of Killing: Face-toFace Killing in Twentieth-Century Warfare (New York, 1999); and Stephen G. Fritz, Endkampf: Soldiers, Civilians, and the Death of the Third Reich (Lexington, KY, 2004), $73-75$.

${ }^{160}$ Helmut Naroska in Scherstjanoi, Wege in die Kriegsgefangenschaft, 154-61, at 158. 
exceptional in the West European theater, they were more common in the Pacific. ${ }^{161}$ Even if the astonishing mass executions during the Rape of Nanjing were the exception rather than the rule, it is nonetheless true that the Japanese army denied quarter often. ${ }^{162}$ On the other side of the front line, too, prisoners were not only shot but their corpses mutilated, stripped of gold teeth, or urinated upon as well. Sometimes, particularly brutalized American marines robbed Japanese of the precious metal in their mouths while the victims were still alive. ${ }^{163}$

Such examples - and other examples from other wars could be added - suggest that wartime barbarism does not rely upon a preexisting "culture" or "civilization" of violence, upon political religions dehumanizing the enemy, or upon dictatorships forcing their soldiers into battle. The dynamics of warfare itself, if not checked by politics, law, and morality, tend toward greater and greater force, and prisoners (or, for that matter, civilians) are not excluded from this maelstrom. ${ }^{164}$ In fact, the logic of the situation — what has been described as the "captor's dilemma"-loads the scales against the survival of prisoners: from a purely instrumental viewpoint, all the benefits of taking prisoners go to the collective the soldier is fighting for (the army and the nation benefit from their labor power, the weakening of enemy resolve, and their potential for yielding intelligence), while all the risks and hardships (the potential that the surrender is a ruse of war, the problem of how to evacuate, guard, and feed the enemy) are borne by the soldier and his primary group. ${ }^{165}$

\section{Diagnosis}

Red Army soldiers' refusal to give quarter, then, was not so special after all. This article has identified several reasons for prisoner killing that are basic aspects of the captor's dilemma. Murders from military necessity, as locally perceived, all fall in this category. Weak discipline worked against some of the potential restraints on such behavior, and the Soviet army's violence toward its own troops in the context of the utter chaos of a fighting retreat further enhanced the likelihood of captured troops being killed. The accumulation of reasons for revenge as the war went on, finally, brought Soviet soldiers into the mainstream

${ }^{161}$ Gerald F. Linderman, The World within War: America's Combat Experience in World War II (New York, 1997).

${ }^{162}$ Masahiro Yamamoto, Nanking: Anatomy of an Atrocity (Westport, CT, 2000), 90106.

${ }^{163}$ E. B. Sledge, With the Old Breed, at Peleliu and Okinawa (Novato, 1990). For a wide-ranging analysis of mutilation of enemy corpses, see Simon Harrison, Dark Trophies: Hunting and the Enemy Body in Modern War (New York, 2012).

${ }^{164}$ Carl von Clausewitz, Vom Kriege. Ungekürzter Text (Munich, 2000).

165 Ferguson, The Pity of War, 371-73. 
of the reasons for killing unarmed enemies. In fact, one might wonder why Red Army soldiers did not kill German POWs more often.

What was special, however, was the time frame involved. All the comparisons cited above were the results of cycles of violence, of the dialectics of anger and revenge, of growing bitterness and embitterment. Most of these crimes happened after years of warfare, of increasing brutalization through the experience and practice of violence. Even in the Pacific, where both sides went to war with racist prejudices against each other, the war became truly merciless only with the passing of time. Historians differ in identifying the moment when the spiral of atrocities and hate propaganda culminated in institutionalized brutality, but they agree on the general path to escalation. ${ }^{166}$ The German-Soviet encounter, by contrast, was a "war without mercy" from day one, quickly escalating further in the summer and fall. As far as the phenomenon of prisoner killing is concerned, it is this temporal fact that made this war different.

From a comparative perspective, then, what needs elucidation is how and why this spiral of violence was so intense and force was unleashed so fast. It is here where prior brutalization, the cultures of violence, and ideological indoctrination came into play. Again, the two sides are different. In the German case, the radicalization of war was deliberate and part of a policy. It was motivated both ideologically and militarily, propagated openly and aggressively, and implemented with the consent of many troops and against the resistance or reluctance of others. ${ }^{167}$ The Soviet case is more complicated. As we have seen, it is hard to identify one single policy line regarding the treatment of POWs. Atrocity propaganda from the first days of the war, Stalin's deliberately vague utterances early in the war, direct orders from field commanders or political officers, and the extrajudicial as well as judicial execution of "enemies" or "spies" all tended to decrease the survival chances of captives. The establishment of POW camps, administrations, procedures, and norms; the unambiguous orders not to kill prisoners; and the interest of the military in intelligence gathering and weakening the enemy all tended toward the opposite. Soldiers and their commanders had to find their way through this confusing jungle of contradictions.

Thus each soldier often had to follow his own moral compass, a fickle needle pointing in different directions for different people at different times. Overall, we need to remember that Soviet soldiers did not enter the war as blank slates, becoming slowly radicalized into German-eaters by experience. Their horizon of

${ }^{166}$ For Linderman, World within War, 157, 173, it was the Guadalcanal campaign of August 1942 to January 1943 that proved decisive in this process. Dower, War without Mercy, 299-300, pushes the turning point back to the final year of the war.

${ }^{167}$ Militärgeschichtliches Forschungsamt, ed., Das Deutsche Reich und der Zweite Weltkrieg, vol. 4, Der Angriff auf die Sowjetunion. Also available in a revised edition as Horst Boog, Jürgen Förster, Joachim Hoffmann, Ernst Klink, Rolf-Dieter Müller, and Gerd R. Ueberschär, Der Angriff auf die Sowjetunion, rev. ed. (Frankfurt, 1991). 
expectation had been formed by the indoctrination and acculturation drive of the Soviet regime ever since the Revolution and by personal experiences with violence, either as perpetrator or victim, or both, in the Civil War, in the war against the peasantry of the early 1930s, in the Great Terror, and in the revolution from abroad and the recurrent, smaller-scale wars between 1938 and $1941 .{ }^{168}$ It needs to be borne in mind, however, that this experience was multifaceted, that different people remembered different things about different pasts, and that indoctrination was uneven within the Soviet population. The predispositions that Soviet citizens brought with them to the front, therefore, were not unitary, but pluralistic. ${ }^{169}$

It was not necessary, however, for everyone to act the same. It was sufficient that there was a large enough core of those who were not prepared to give any quarter. The quickly spreading stories of German atrocities, disseminated through the rumor mill and immediately taken up by official media, together with personal experiences with this enemy did the rest to draw more and more soldiers into the inner circles of atrocity in the winter of 1941. Only when strong signals were sent from above that such escalation was counterproductive was the widening of the circle of perpetrators slowed. Later, as the Red Army entered foreign soil, this deescalation was undone in order to motivate the troops to continue fighting after the liberation of the homeland. Now, the victims of the renewed radicalization drive became, more often than not, German civilians - a different story that others have already told in detail. ${ }^{170}$

${ }^{168}$ See Weiner, "Something to Die For"; and Weiner, "Saving Private Ivan.” This thesis is the corollary to Barber and Harrison's insight that the continuum of violence, upheaval, and extreme hardship since 1914 had prepared the population well for the war. See John Barber and Mark Harrison, The Soviet Home Front, 1941-1945: A Social and Economic History of the USSR in World War II (London, 1991), 77. The terms "war against the peasantry" and "revolution from abroad" belong to Lynne Viola and Jan Gross, respectively. See Lynne Viola, V. P. Danilov, N. A. Ivnitskii, and Denis Kozlov, eds., The War Against the Peasantry, 1927-1930 (New Haven, CT, 2005); and Jan T. Gross, Revolution from Abroad: The Soviet Conquest of Poland's Western Ukraine and Western Belorussia, expanded ed. (Princeton, NJ, 2002).

${ }_{169}$ Mark Edele, Stalinist Society 1928-1953 (Oxford, 2011).

${ }^{170}$ Careful recent studies of Soviet troop violence at war's end and after include Barbara Stelzl-Marx, Stalins Soldaten in Österreich. Die Innensicht der sowjetischen Besatzung 1945-1955 (Vienna, 2012); and Filip Slaveski, The Soviet Occupation of Germany: Hunger, Mass Violence, and the Struggle for Peace, 1945-1947 (Cambridge, 2013). For my own take, see Mark Edele, "Soviet Liberations and Occupations, 19391949," in The Cambridge History of the Second World War, vol. 2, ed. R. J. B. Bosworth and J. Maiolo (Cambridge, 2015), 487-506; Mark Edele and Filip Slaveski, "Violence from Below: Explaining Crimes against Civilians across Soviet Space, 1943-1947," Europe-Asia Studies, forthcoming. 